\title{
32. GEOCHEMICAL AND ISOTOPIC EVIDENCE FOR FLUID FLOW IN THE WESTERN NANKAI SUBDUCTION ZONE, JAPAN ${ }^{1}$
}

\author{
Miriam Kastner, ${ }^{2}$ Henry Elderfield, ${ }^{3}$ William J. Jenkins, ${ }^{4}$ Joris M. Gieskes, ${ }^{2}$ and Toshitaka Gamo ${ }^{5}$
}

\begin{abstract}
At the Western Nankai Trough subduction zone at ODP Site 808, chemical concentration and isotopic ratio depth profiles of $\mathrm{D}, \mathrm{O}, \mathrm{Sr}$, and $\mathrm{He}$ do not support fluid flow along the décollement nor at the frontal thrust. They do, however, support continuous or periodic lateral fluid flow: (1) at the base of the Shikoku Basin volcanic-rich sediment member, situated $\sim 140 \mathrm{~m}$ above the décollement, and particularly (2) below the décollement. The latter must have been rather vigorous, as it was capable of transporting clay minerals over great distances. The fluid at $\sim 140 \mathrm{~m}$ above the décollement is characterized by lower than seawater concentrations of $\mathrm{Cl}-\left(\geq 18 \%\right.$ seawater dilution). It is ${ }^{18} \mathrm{O}$-rich and D-poor and has a non-radiogenic, oceanic, or volcanic arc $\mathrm{Sr}$ isotopic signature. It originates from "volcanic" clay diagenesis. The fluid below the décollement has also less $\mathrm{Cl}^{-}$than seawater ( $>20 \%$ dilution), is more enriched in ${ }^{18} \mathrm{O}$ and depleted in $\mathrm{D}$ than fluid, but its $\mathrm{Sr}$ isotopic signature is radiogenic, continentalterrigenous. The source of this fluid is located arcward, is deep-seated, where illitization of the subducted clay minerals, a mixture of terrigenous and volcanic clays, occurs. The ${ }^{3} \mathrm{He}{ }^{4} \mathrm{He}$ ratio below the décollement points to an $-25 \%$ mantle contribution.

The nature of the physical and chemical discontinuities across the décollement suggests it is overpressured and is forming a leaky "dynamic seal" for fluid flow. In contrast with the situation at Barbados and Peru, where the major tectonic features are mineralized, here, although the complex is extremely fractured and faulted, mineralized macroscopic veins, fractures, and faults are absent. Instead, mineralized microstructures are widespread, indicating a diffuse mode of dewatering.
\end{abstract}

\section{INTRODUCTION}

It is well established that fluids affect virtually all aspects of the geologic evolution in the special environment of subduction zones, and that fluids play a central role in the deformational, thermal, and geochemical evolutions of this environment (von Huene, 1984; Bray and Karig, 1985; Fowler et al., 1985; Brown and Westbrook, 1988; Fisher and Hounslow, 1990; Foucher et al., 1990; Moore et al., 1990). Here extensive fluid-solid diagenetic and metamorphic reactions take place (Boulègue et al., 1987; Ritger et al., 1987; Peacock, 1990; Elderfield et al., 1990; Gieskes et al., 1990; Kastner et al., 1990, 1991; Taira, Hill, Firth, et al., 1991), and significant fluid volumes are expelled (Carson, 1977; Carson et al., 1990; Westbrook and Smith, 1983; von Huene, 1984; von Huene and Scholl, 1991; Kulm et al., 1986; Taira et al., 1986; COSOD II, 1987; Moore et al., 1988; Langseth et al., 1988; Carson et al., 1990; Le Pichon et al., 1990, 1991, 1992). These fluids may play an important role in global geochemical and heat budgets (COSOD II, 1987; Han and Suess, 1989; Kastner et al., 1991; Martin et al., 1991). It is, therefore, critical to thoroughly understand the fluid regimes at subduction zones to gain insight into the relationships between deformation processes and hydrogeology. Documenting the rock mechanical properties, diagenesis, and metamorphism is imperative for calculating geochemical and thermal budgets in subduction zones.

Typically, the sediments entering subduction zones have porosities of approximately $50 \% \pm 10 \%$ following basinal compaction (e.g., Hamilton, 1976), while the subaerially exposed accretionary complex sediments have porosities of less than $5 \%-10 \%$. The fluids expelled by this porosity reduction as well as by other internal processes, such as thermal dehydration and decomposition of hydrous minerals, must move through these same sediment complexes, thereby producing

\footnotetext{
'Hill, I.A., Taira, A., Firth, J.V., et al., 1993. Proc. ODP, Sci. Results, 131: College Station, TX (Ocean Drilling Program).

${ }^{2}$ Scripps Institution of Oceanography, University of California, San Diego, La Jolla, CA 92093 , U.S.A.

${ }^{3}$ Department of Earth Sciences, University of Cambridge, Cambridge CB2 3EQ, United Kingdom.

${ }^{4}$ Woods Hole Oceanographic Institution, Woods Hole, MA 02543, U.S.A.

${ }^{5}$ Ocean Research Institute, University of Tokyo, Nakano, Tokyo 164, Japan.
}

active fluid regimes within these geologic settings and fluid fluxes into the ocean. The total volume of these internal fluids, of $1-2 \mathrm{~km}^{3} / \mathrm{yr}$, has been estimated, e.g., by Carson (1977), COSOD II (1987), Le Pichon et al. (1990, 1991, 1992), von Huene and Scholl (1991), and Kastner et al. (1991). Studies of their geochemical and isotopic compositions permit an evaluation of the types and extent of fluidrock reactions that have occurred, and possibly even a detection of mixing with external fluids, principally with meteoric water.

Studies of surface venting phenomena and of the geochemistry of the associated fluids at convergent margins provide integrated signals of the evolution of some of the fluids in accretionary complexes, and studies of ancient, subaerially exposed accretionary complexes provide important information on the overall long-term relations between fluids and the geologic evolution of convergent margins. But studies of active convergent margins through drilling provide a unique opportunity to examine the dynamics of the systems, the active fluid-rock reactions, and to link these processes with in-situ physical-chemical parameters related to fluid flow. Particularly, a combined fluid-solid analysis approach provides not only the snapshot and/or integrated view acquired from a fluids-only study, but also a time-integrated record of solutes and heat transport by the fluids, stored in the diagenetic and metamorphic phases.

The relative importance of channelized, localized fluid flow, that is spatially restricted in its diagenetic and metamorphic effects, vs. pervasive, lateral and vertical diffusive flow, affecting larger terrains, as yet unknown, is critical to the understanding of the hydrogeology of subduction zones. For obvious reasons, most attention has been given to the widespread venting which supports extensive benthic biological communities (Kulm et al., 1986; Taira et al., 1986; Boulègue et al., 1987; Le Pichon et al., 1992), mud volcanoes and diapirs, carbonate chimneys (e.g., Westbrook and Smith, 1983; Ritger et al., 1987; Brown and Westbrook, 1988; Langseth et al., 1988; Carson et al., 1990; Henry et al., 1990) and heat-flow anomalies (Fisher and Hounslow, 1990; Foucher et al., 1990). All of these phenomena are important direct manifestations of localized fluid expulsion in accretionary complexes. Information about both diffuse and localized fluid expulsion is provided indirectly by seismic studies, e.g., of arcward thinning of the underthrusted sediments (e.g., Bray and Karig, 1985; Fowler et al., 1985; Bangs et al., 1990), by physical 
and thermal properties and mechanical state of the sediments (Taira, Hill, Firth, et al., 1991; Karig, 1992), by means of carbonate crusts and cements, and mineralized veins (Kemp, 1990; Lindsley-Griffin et al., 1990; Kulm et al., 1990; Kulm and Suess, 1990; Vrolijk, 1987; Vrolijk and Sheppard, 1991), and by the presence at shallow depths of chemical and isotopic signatures typical of deep-seated reactions, e.g., the thermogenic methane in the Barbados Ridge décollement (Vrolijk et al., 1990).

Although the eastern region of the Nankai Trough was drilled before, during DSDP Legs 31 and 87 (Ingle, Karig, et al., 1975; Kagami, Karig, Coulbourn, et al., 1986, respectively), drilling failed to penetrate through the décollement zone. The western Nankai region chosen for drilling on ODP Leg 131, which has been extensively surveyed, is structurally relatively simple, has the highest regional heat flow (HF), with an areal HF distribution indicative of channelized fluid flow, the sediment section is thin and the décollement zone shallow, thus reachable by drilling (Moore et al., 1990; Taira, Hill, Firth, et al., 1991; Taira et al., 1992; Yamano et al., 1992, and references therein) (Fig. 1). Also, the western Nankai accretionary complex sediments, which are silt- and sand-rich, provide a prime contrast with the clay-rich sediments of the only other site that successfully drilled through a décollement, ODP Site 671, at the northern Barbados Ridge (Moore et al., 1988). ODP Site 808 drilled successfully through a frontal thrust zone, at 340-390 mbsf, and through the décollement zone, at 945-965 mbsf; oceanic basement of 14-16 Ma was touched at 1290 mbsf (Taira, Hill, Firth, et al., 1991).

Notably, the chemical depth profiles of ODP Site 808, obtained on board the Resolution, showed no conclusive evidence for pervasive channelized fluid flow, either at the décollement or at the frontal thrust zones. Also, no macroscopic mud-filled or mineralized veins were noticed at these and at other faulted and fractured horizons. It was therefore concluded that, unlike at the Northern Barbados Ridge or nearby at the eastern region of the Nankai Trough, here pervasive diffusive fluid flow seems to be the predominant mode of dewatering. At Barbados and eastern Nankai, fluid flow seems to be primarily channelized, controlled by the major active faults (e.g., Moore et al., 1988; Le Pichon et al., 1992, respectively).

The new data on the isotopic compositions of the pore fluids, on some diagenetic minerals, and on microveins above, within, and below the décollement zone, provide new insights into the nature of fluid flow in the western Nankai Trough and on the origin of the fluid. An attempt to integrate our new geochemical and mineralogical results with the chemical, sedimentological, structural, and thermal data summarized in Taira, Hill, Firth, et al. (1991); Gieskes et al. (1992); Karig (1992); Maltman et al. (1992); and Yamano et al. (1992), is presented below. The focus is on fluid flow within the Shikoku Basin sediment section.

\section{BACKGROUND EVIDENCE AND KEY QUESTIONS}

At ODP Site 808 , the lithological section consists of $\sim 560 \mathrm{~m}$ of trench-fill sandy-silty turbidites, a $\sim 60-\mathrm{m}$ transition zone, and from 620 to $1245 \mathrm{mbsf}, 625 \mathrm{~m}$ of bioturbated hemipelagic mudstones of the Shikoku Basin. The oceanic basement, which was encountered at 1290 mbsf, is overlain by a $\sim 45-\mathrm{m}$ thick, dominantly silicic, basal volcaniclastic unit. The youngest, uppermost $200 \mathrm{~m}$ of the Shikoku

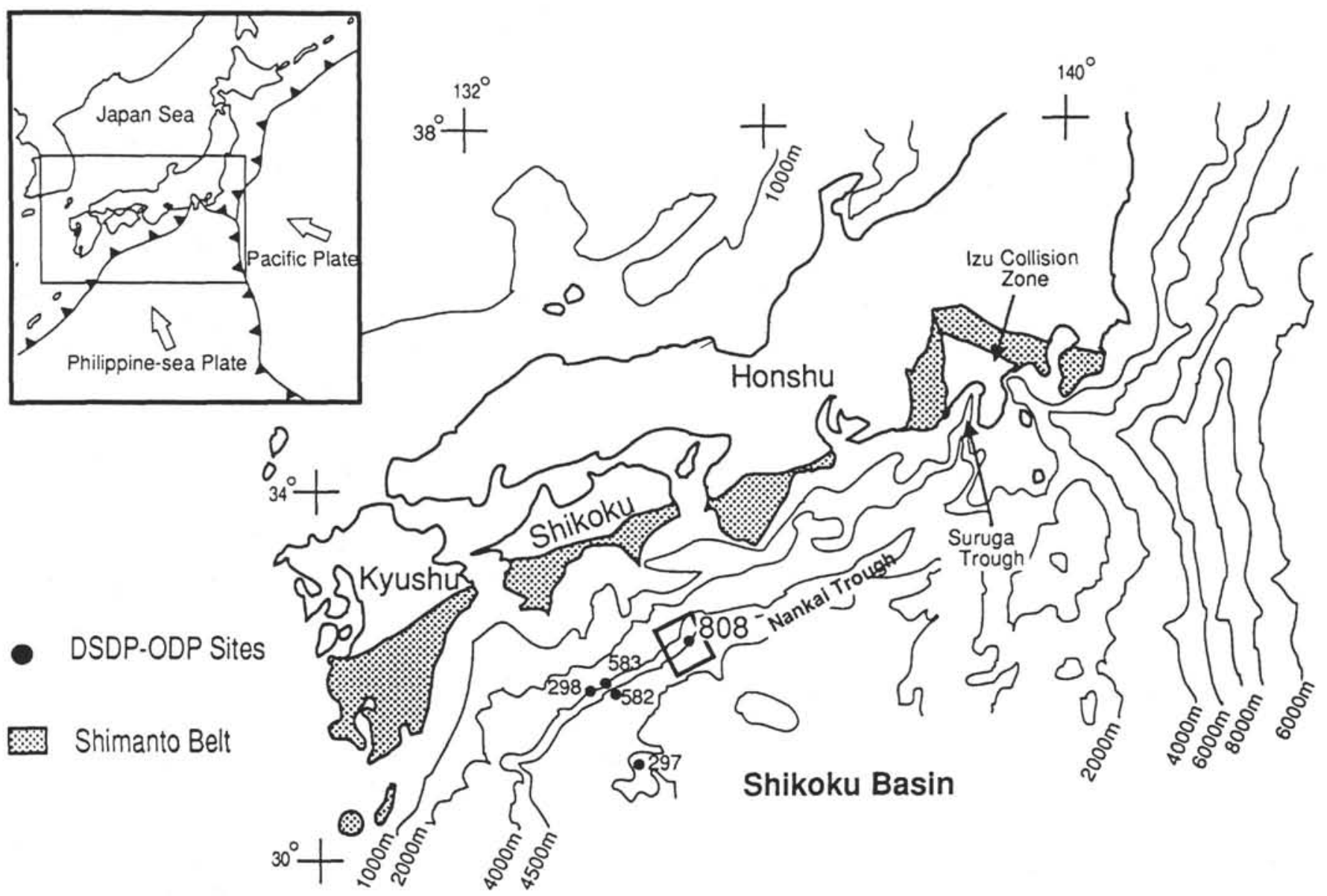

Figure 1. Location of the Nankai Trough and Site 808. Locations of sites drilled on DSDP Legs 31 and 87 are also shown (from Taira et al., 1992, fig. 2). 
Basin sediments also have abundant volcanic ash. Interestingly, an "extension" of a "proto-thrust" is positioned at the boundary between the volcanic-rich and volcanic-poor sections of the Shikoku Basin hemipelagic mudstones, at $\sim 820$ mbsf, as shown in Figure 2 (Underwood et al., 1992; Taira, Hill, Firth, et al., 1991).

In principle, the measured heat flow (HF) of $125-130 \mathrm{~mW} / \mathrm{m}^{2}$ is consistent with the age of the subducting plate. However, the surface HF should have been lowered by $\sim 20 \%$ by the rapid sedimentation of the trench-fill turbidites (Yamano et al., 1992). Thus, to sustain the considerably higher HF observed hot water flow is necessary; compactive dewatering alone would not suffice. The existence of a discrepancy between the observed and anticipated HF led Yamano et al. (1992) to conclude that substantial active lateral and/or upward diffusive hot fluid transport, in excess of the pore fluid available from compactive dewatering, must prevail in this region of the Nankai trough.

\section{The Décollement Zone}

Curiously, the décollement zone, only $\sim 20 \mathrm{~m}$ thick, is situated within the lower Shikoku Basin sediments, at a depth of 945-965 mbsf, where no obvious lithologic or stratigraphic discontinuities exist (Fig. 2). The zone of the décollement is characterized by intense fracturing and brecciation, as well as by relative low porosities (Taira, Hill, Firth, et al., 1991). Is this zone of lowest strength within a homogeneous lithology maintained by having the highest pore fluid pressure, sustained by an overpressured fluid conduit? If so, this should be reflected in the geochemical concentration anomalies at the décollement zone or at the frontal thrust (Taira, Hill, Firth, et al., 1991; Gieskes et al., 1992), but none have been observed. Also, unlike at the Barbados or Peru margin accretionary complexes (Vrolijk, 1990; Vrolijk et al., 1991; Kemp, 1990, and Lindley-Griffin et al., 1990, respectively), where mineralized and/or mud-filled veins and fractures are common, in the western Nankai Trough, except for a $\sim 2 \mathrm{~cm}$ clastic breccia dike at $\sim 800$ mbsf (Taira, Hill, Firth, et al., 1991; Maltman et al., 1992), none were conspicuous throughout the sediment section, even in the particularly extensively faulted and fractured zones of the décollement and the frontal thrust. This suggests no present or past significant channelized fluid flow in this region of the Nankai trough. In contrast, the minor mineralization along the extremely abundant small faults, described by Maltman et al. (1992), implies that, overall, even in an assumed diffuse system, channelized dewatering may prevail through a complex network of microfaults, and fractures acting as microconduits.

Another significant finding, directly linked with the fluid flow regime of this system, is the sharp $\sim 10 \%$ porosity increase (plus discontinuities in all other index physical properties) across the décollement zone, with the lowest values in the zone of décollement (Fig. 3) (Taira, Hill, Firth, et al., 1991). Also the compaction-depth profiles indicate that the sediment section is over-consolidated above and within the décollement zones, but is underconsolidated below it (Taira, Hill, Firth, et al., 1991; Karig et al., 1990; Karig, 1992). These suggest that present transport of fluid across the décollement is highly impeded, thus leading to a "dynamic" seal (Karig et al., 1990) and preventing the considerably "wetter" subducted sediments from being drained in the upward direction. Keeping the décollement overpressured does not necessitate pervasive fluid flow along it. A leaky décollement is, however, imperative and consistent with the chemical depth profiles, shown in Figure 4 (Taira, Hill, Firth, et al., 1991; Gieskes et al., 1992). No diagenetic barrier to vertical drainage across the décollement has yet been found. Although the chemical concentration profiles do not provide evidence of active fluid flow along the décollement, several of these profiles, especially those of $\mathrm{Li}, \mathrm{Sr}$, silica, B, and dissolved organic matter (Taira, Hill, Firth, et al., 1991; You et al., 1992), are either discontinuous or have maxima with elevated concentrations across the décollement. These chemical discontinuities may, however, simply reflect the variance in physical (and ther- mal?) properties across the décollement zone. Furthermore, unlike at Barbados, where the sediments below the décollement are somewhat deformed (Moore et al., 1988), here they are undeformed (Maltman et al., 1992). In summary, the zone below the décollement is a high pore pressure zone of no net drainage (Karig, 1992) with distinct chemical signatures.

Interestingly, some of the concentration depth profiles, shown in Figure 4, have even sharper minima and/or maxima above the décollement, at the $\sim 820$ mbsf horizon, than immediately below it, especially the profiles of $\mathrm{Cl}, \mathrm{Na}, \mathrm{Li}, \mathrm{Sr}$, and silica. This depth horizon marks the boundary between the upper volcanic ash-rich and the lower volcanicpoor Shikoku Basin sediments (Underwood et al., 1992) and coincides with an "extension" of a proto-thrust zone toward the frontal thrust (Fig. 2). Are these chemical discontinuities maintained by upward and lateral active fluid flow through this horizon, or are they controlled by a diagenetic front related to volcanic ash alteration reactions?

\section{The Frontal Thrust Zone}

The concentration reversals in the depth range of the frontal thrust (340-390 mbsf) (Fig. 4), indicative of vertical displacement associated with this thrust, suggest that as yet, in-situ diagenetic reactions had little effect on the chemical profiles, i.e., that diffusion has not yet erased the concentration gradients; the frontal thrust must thus be a rather young tectonic feature. Assuming diffusion coefficients of $2-5 \times 10^{-6} \mathrm{~cm}^{2} / \mathrm{s}$, the thrust must be younger than 10,000 to 20,000 yr (Taira, Hill, Firth, et al., 1991; Gieskes et al., 1992). Also, a normal compaction gradient has not been reestablished across the frontal thrust zone, thus supporting the notion that the frontal thrust is very young. The youthfulness of the frontal thrust plus the long pathway, of $\sim 1250 \mathrm{~m}$, between its intersections with the décollement and with Hole $808 \mathrm{C}$, may explain the lack of evidence for active fluid transport along the frontal thrust zone at this site. At flow rates of $1-4 \times$ $10^{-9} \mathrm{~m} / \mathrm{s}$, it would take 4,000 to $10,000 \mathrm{yr}$, respectively, for a fluid parcel entering the frontal thrust at the décollement, to reach the intersection point with Hole $808 \mathrm{C}$, and certainly a longer time at slower flow rates. The distance to the intersection of the extension of the proto-thrust with ODP Hole $808 \mathrm{C}$ at $\sim 820$ mbsf (Fig. 2 ) is $\sim 10 \%$ shorter. In addition, the $820 \mathrm{mbsf}$ horizon is situated within the deeper and older portion of the sediment column. It thus may have originally evolved as the preferred conduit.

The other horizon of geochemical discontinuities, at the boundary between the trench-fill turbidites and the Shikoku Basin hemipelagic mudstones at $\sim 560 \mathrm{mbsf}$, seen in Figure 4 , will not be considered here.

\section{THE ENIGMATIC CHLORIDE DEPTH PROFILE}

Despite the absence of a clear $\mathrm{Cl}^{-}$concentration anomaly along the décollement at Site 808 , its concentration depth profile is striking. It is characterized by a broad region of lower than seawater $\mathrm{Cl}^{-}$ concentrations that spans the entire Shikoku Basin sediment section between 560 and 1240 mbsf. The maximum seawater dilution, of $\sim 20 \%$ ( $447 \mathrm{mM}$ ), the minimum of the profile, occurs at $1110 \mathrm{mbsf}$. Lower than seawater $\mathrm{Cl}^{-}$pore fluids are ubiquitous in subduction zones (e.g., Gieskes et al., 1990; Kastner et al, 1990, 1991; Le Pichon, 1990). But unlike at Nankai, the Barbados and Peru subduction zones have distinctly non-steady-state $\mathrm{Cl}^{-}$profiles, with $\mathrm{Cl}^{-}$minima situated at unconformities, faults and at the décollement. Some of these $\mathrm{Cl}^{-}$ minima are also associated with thermal anomalies (Fisher and Hounslow, 1990), indicating active lateral fluid flow.

The origin of the ubiquitous low $\mathrm{Cl}^{-}$fluids has been discussed extensively before; e.g., by Gieskes et al. (1990); Vrolijk et al. (1990); Elderfield et al. (1990); and Kastner et al. (1990, 1991). Accordingly, the four important possible $\mathrm{Cl}^{-}$diluting sources are: (1) gas hydrates dissociation, (2) hydrous minerals, especially clay minerals, dehydration, and breakdown, (3) clay membrane ion filtration, and (4) mixing 

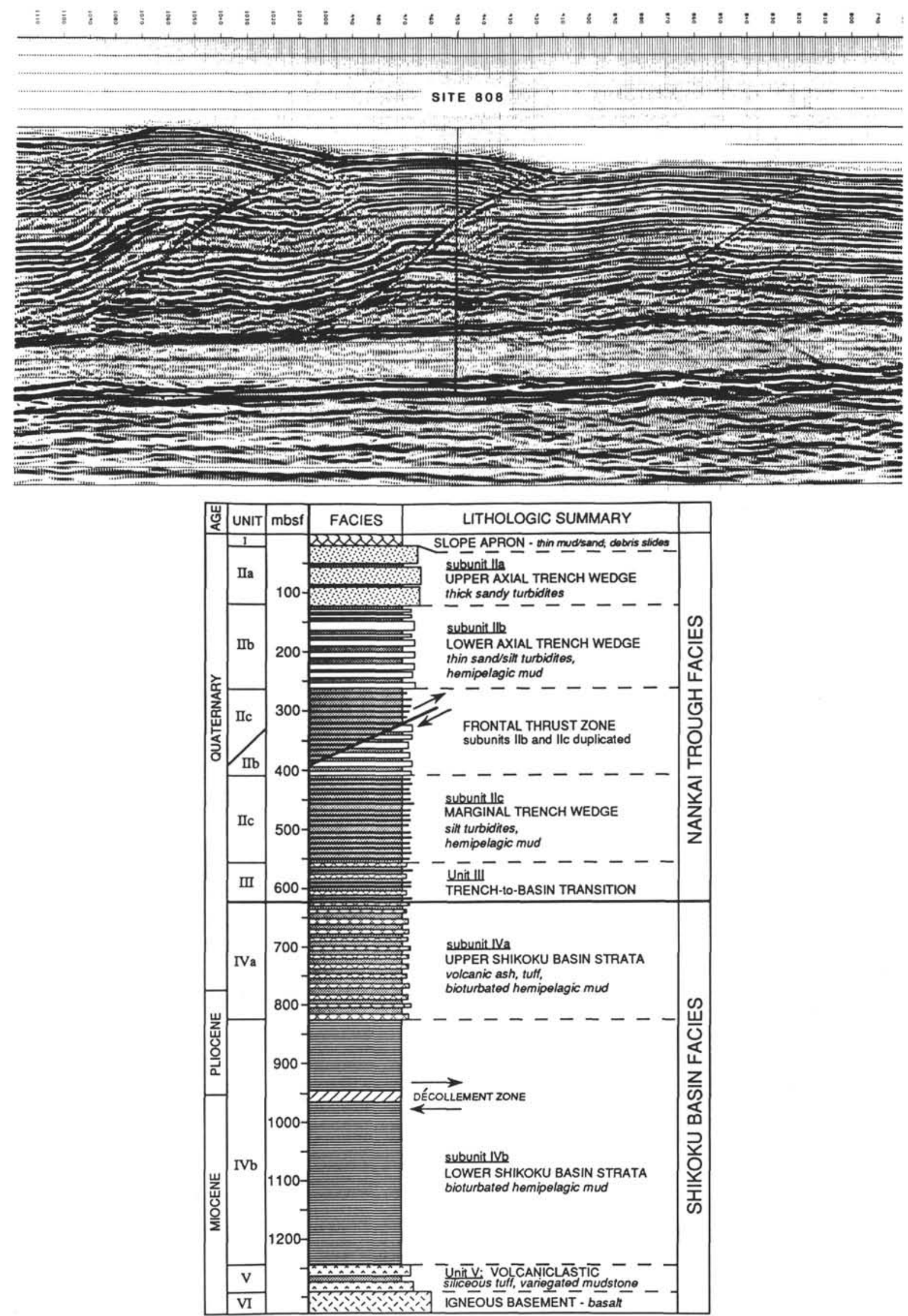

Figure 2. A segment of the seismic reflection profile of the western Nankai subduction zone with location of Site 808 and summary of lithological section. 


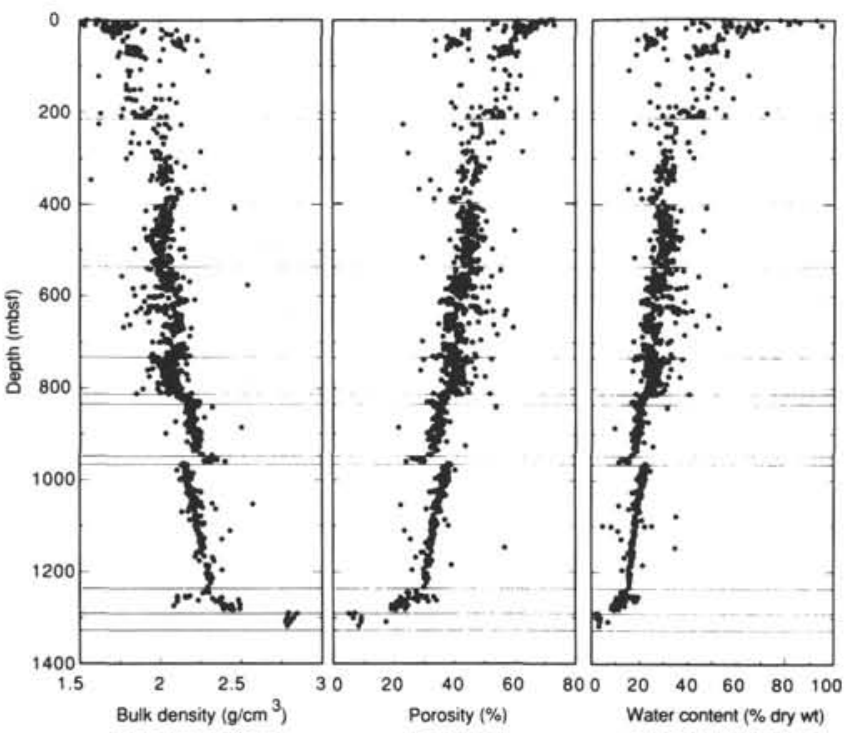

Figure 3. Depth profiles of bulk density $\left(\mathrm{g} / \mathrm{cm}^{3}\right)$, porosity $(\%)$, and water content (\%dry wt), Site 808 (from Taira, Hill, Firth, et al., 1991).

with meteoric water. Which of these are the important sources at the western region of the Nankai trough?

Because of the high heat flow at Site 808 of $125-130 \mathrm{~mW} / \mathrm{m}^{2}$ (Taira, Hill, Firth, et al., 1991; Yamano et al., 1992), extrapolation of the bottom-simulating reflector (BSR), which supposedly delineates the base of the stability field of the gas hydrates (Claypool and Kaplan, 1974; Shipley et al, 1979; Kvenvolden and McMenamin, 1980), from $\sim 20 \mathrm{~km}$ arcward of the trench to Site 808 results in a depth of $230 \pm$ 12 mbsf for the base of the methane hydrate stability, within the trench-fill turbidites (Taira, Hill, Firth, et al., 1991; Taira et al., 1992; Moore et al., 1990; Hyndman et al., 1992). The extrapolated BSR is thus located $330 \mathrm{~m}$ above the upper boundary of the low $\mathrm{Cl}^{-}$zone, and $880 \mathrm{~m}$ above the $\mathrm{Cl}^{-}$minimum horizon. Therefore gas hydrates are an unlikely $\mathrm{Cl}^{-}$diluting source of the underlying Shikoku Basin sediments. The pore-fluid oxygen isotope values, to be discussed below, support this conclusion, and also indicate that membrane ion filtration is not an important seawater diluting source at this location. As yet, little is known about the importance of meteoric water infiltration to great depths and distances in this or in other subduction zones. However, at this geographic location and stratigraphic depth of the $\mathrm{Cl}^{-}$ minimum, below the décollement, infiltration of meteoric water seems rather unlikely. Hence, in the following discussion, only the last option, the hydrous (principally clay) minerals dehydration and transformation reactions, which seem to be the important one for the pore-fluid $\mathrm{Cl}^{-}$ dilution in the western Nankai trough, will be emphasized.

The prime clay mineral reaction is the smectite(S) to illite (I) $(\mathrm{S} \rightarrow \mathrm{I})$ transformation, which releases water (plus other chemical constituents) and may induce high pore-fluid pressures (e.g., Powers, 1967; Burst, 1969; Perry and Hower, 1972; Hower et al., 1976; Colton-Bradley, 1987; Freed and Peacor, 1989; Fisher and Boles, 1990; Whitney, 1990; and references therein). Based on experimental and empirical studies (for example, Eberl and Hower, 1976; Hower et al., 1976; Freed and Peacor, 1989; Walker and Thompson, 1990), the optimal temperature range for the initiation and completion of this reaction is higher in young, $<2-$ m.y.-old systems, from $\sim 60^{\circ}-150^{\circ} \mathrm{C}$ than in older $>5-10$-m.y.-old systems, where the optimal temperature range is $\sim 60^{\circ}-120^{\circ} \mathrm{C}$ (e.g., Perry and Hower, 1972, Hower et al., 1976; Freed and Peacor, 1989; Walker and Thompson, 1990). These optimal temperature ranges depend also on a multitude of other factors, primarily on the physical and chemical properties of the sediments and pore fluids. A more detailed discussion of clay diagenesis at this site is given in Underwood et al., this volume.
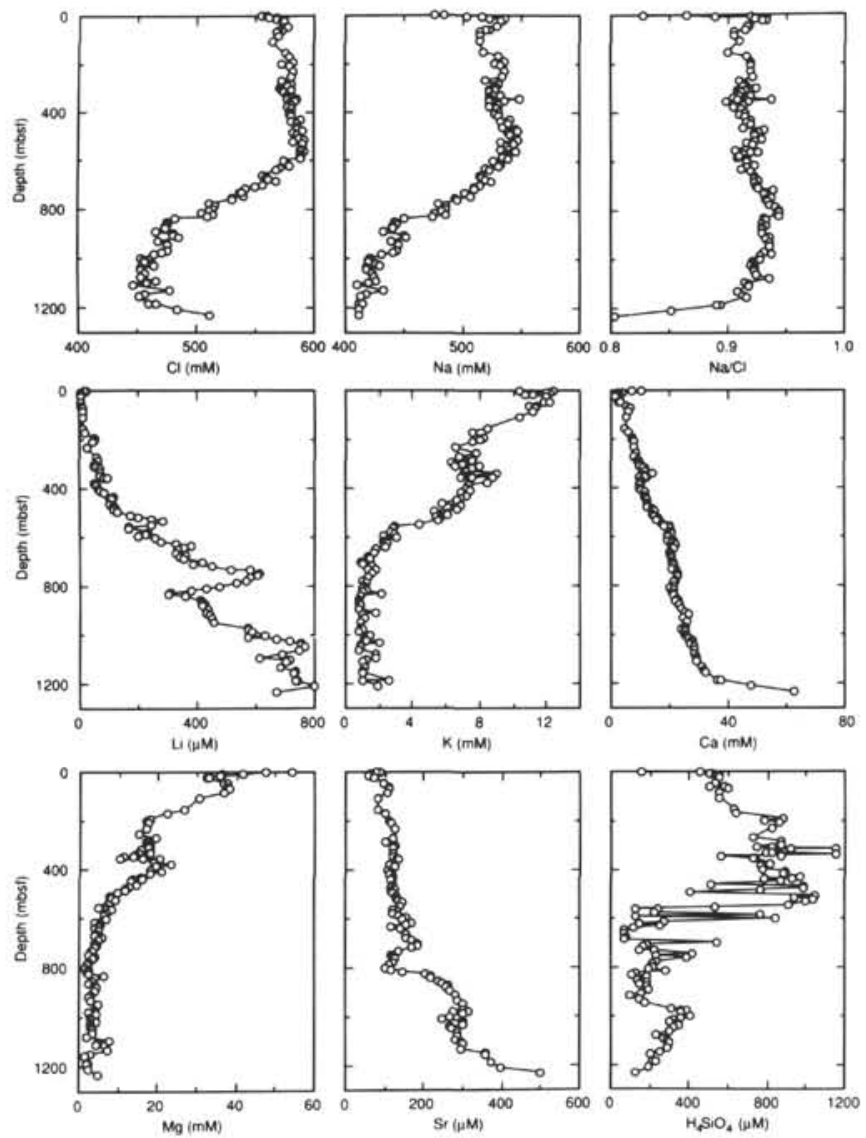

Figure 4. Summary of pore-fluid concentration depth profiles of Site 808. (See also Gieskes et al., this volume.)

At Site 808 , with an average geothermal gradient of $\sim 110^{\circ} \mathrm{C} / \mathrm{km}$ (Taira, Hill, Firth, et al., 1991) and $2^{\circ} \mathrm{C}$ bottom-water temperature, the calculated depth of the onset of this reaction coincides with the top of the low $\mathrm{Cl}^{-}$zone; the extrapolated temperature at this depth, $\sim 560 \mathrm{mbsf}$, is presently $60^{\circ}-65^{\circ} \mathrm{C}$. Its burial began with the rapid deposition of the overlying trench-fill turbidites that started only $0.46 \mathrm{Ma}$ (Taira, Hill, Firth, et al., 1991). Based on the assumption that the geothermal gradient of $\sim 110^{\circ} \mathrm{C} / \mathrm{km}$, obtained in the top $400 \mathrm{~m}$ of the sediment column, remains linear with depth, the calculated temperature at the base of the Shikoku Basin mudstones, at $\sim 1200 \mathrm{mbsf}$, is $130^{\circ}-135^{\circ} \mathrm{C}$. Assuming equilibrium reactions, the $\mathrm{Mg}$-Li geothermometer (Kharaka and Mariner, 1989), however, gives a somewhat lower calculated temperature of $\sim 120^{\circ} \mathrm{C}$ at this depth, and a lower geothermal gradient below the décollement, of $\sim 60 \% \mathrm{~km}$. (For these calculations the pore fluids $\mathrm{Li}$ and $\mathrm{Mg}$ concentrations of Sections 131-808C-77R-4 and $-96 \mathrm{R}-1$ were used, with $\mathrm{Li}$ concentrations of 758 and $799 \mu \mathrm{M}$ and $\mathrm{Mg}$ concentrations of 2.99 and $2.43 \mu \mathrm{M}$, respectively.) Regardless of the exact temperature at the base of the section, because of its young age, even at these elevated temperatures, $>100^{\circ} \mathrm{C}$, the smectite-to-illite reaction could not have reached completion.

Is it thus plausible that the conspicuously systematic pore-fluid dilution below $\sim 560 \mathrm{mbsf}$, clearly seen in the concentration depth profile of the conservative component $\mathrm{Cl}^{-}$(Fig. 4), simply reflects the in-situ production of $\mathrm{H}_{2} \mathrm{O}$ through the $\mathrm{S} \rightarrow$ I reaction. The distinct change in the slope of this profile at $\sim 820 \mathrm{mbsf}\left(\sim 90^{\circ} \mathrm{C}\right)$ may be rate-dependent, that is, with increasing percent illite interlayering, the reaction rate decreases. The clay diagenesis data obtained by Underwood et al. (1992) do not support this hypothesis, because although smectite behaves diagenetically as expected, the total amount of smectite available for transformation to illite is, however, much too 
small to produce in-situ the volume of fresh water required to generate the $20 \%$ dilution of seawater observed at this site. The first disordered mixed layer S/I appears at $555 \mathrm{mbsf}\left(\sim 60^{\circ} \mathrm{C}\right)$. At $900 \mathrm{mbsf}\left(\sim 100^{\circ} \mathrm{C}\right)$ the percent of illite interlayering in the S/I reaches $30 \%$. In addition, the initial ordering of the S/I mixed layer, which is expected at $\sim 60 \%-70 \%$ illite layers (Perry and Hower, 1972; Hower et al., 1976), is only first noticed at $1060 \mathrm{mbsf}$, in the $<0.2-\mu \mathrm{m}$ size fraction, and at $1220 \mathrm{mbsf}$ in the coarser, $<2-\mu \mathrm{m}$ size fraction.

The average total clay minerals content at Site 808 is $\sim 20 \%$. Smectite comprises $\sim 10 \%$ of the total clay minerals in the trench-fill turbidites, $\sim 25 \%$ of the Shikoku Basin clays above the décollement, of which half is derived from alteration of volcanic ash and $~ 10 \%$ below the décollement (Underwood et al., this volume). Thus, detrital smectite comprises at best $<3-4 \mathrm{wt} \%$ of the bulk sediment. Overall, the amounts of smectite obtained in the eastern region of the Nankai Trough, DSDP Legs 31 and 87 sediments (Cook et al., 1975; Chamley et al., 1986, respectively), are not significantly higher.

The average porosity of the Shikoku basin sediments above the décollement is $40 \%$ (Taira, Hill, Firth, et al., 1991). A 20\% in-situ dilution of the $\mathrm{Cl}^{-}$concentration, solely by the $\mathrm{S} \rightarrow \mathrm{I}$ reaction, requires the sediment to consist of $\sim 50 \%$ smectite and for all the smectite to completely transform to illite (assuming $15 \mathrm{wt} \%$ interlayer water, $\sim 6 \%$ structural water in the smectite, and a total of $8.5 \mathrm{wt} \% \mathrm{H}_{2} \mathrm{O}$ in illite). In the Shikoku Basin sediments, the smectite concentration is, however, 15-20 times lower, and only a very small fraction of it $(<10 \%)$ has transformed to illite. In summary, the maximum volume of $\mathrm{H}_{2} \mathrm{O}$ produced by the observed in-situ $\mathrm{S} \rightarrow \mathrm{I}$ reaction could at best account for $\mathrm{a} \sim 1 \%$ dilution of the $\mathrm{Cl}^{-}$concentration profile at this site.

Conversely, the diagenetic formation of smectite and zeolites from volcanic ash consumes voluminous $\mathrm{H}_{2} \mathrm{O}$. On the average, smectite contains $22 \mathrm{wt} \% \mathrm{H}_{2} \mathrm{O}$, analcite $8 \%$, and heulandite $\sim 15 \%$. The observed diagenetic formation of approximately $3 \mathrm{wt} \%$ smectite and $2 \%$ zeolite (a mineralogically mixed assemblage of analciteheulandite) of the bulk sediment in these Shikoku Basin sediments of $40 \%$ average porosity, would consume substantial $\mathrm{H}_{2} \mathrm{O}$, leading to an inverse in $\mathrm{Cl}^{-}$concentration of $\sim 3 \%$. The residual pore fluid will be more concentrated in $\mathrm{Cl}^{-}$than seawater, resulting in a positive $\mathrm{Cl}^{-}$depth profile instead of the diluted one encountered at Site 808. Thus the net result from all in-situ $\mathrm{H}_{2} \mathrm{O}$ production and consumption reactions occurring within this section is a $2 \%-3 \%$ increase in the $\mathrm{Cl}^{-}$concentration. Hence, to produce the $\mathrm{Cl}^{-}$profile shown in Figure 4, a significant volume of a low $\mathrm{Cl}^{-}$fluid (at least a $22 \%-24 \%$ diluted seawater by fresh water) must be introduced from somewhere else in the subduction zone. What is the origin of this dilute fluid? Has it advected from deeper sections of the subduction zone and/or migrated laterally from a more altered arcward section of the accretionary complex?

Because evidence for active fluid flow along the décollement is lacking, one probable solution to the problem may be that some time ago, through an intense transient advective pulse, a low $\mathrm{Cl}^{-}$fluid was introduced along the décollement and advected, about $\sim 150 \mathrm{~m}$, to the 820 mbsf level (Fig. 4). In that case the $\mathrm{Cl}^{-}$minimum, originally at the décollement, would have migrated diffusively downward as a result of the differential in physical properties above and below the décollement (Taira, Hill, Firth, et al., 1991). The minimum time needed to establish the very long, $>250 \mathrm{~m}, \mathrm{Cl}^{-}$diffusion profile between 820 and $560 \mathrm{mbsf}$ (Fig. 4) assuming a bulk diffusion coefficient of $1 \times 10^{-5} \mathrm{~cm}^{2} / \mathrm{s}$, is $\sim 3 \times 10^{5} \mathrm{yr}$, approximately $1.5 \times 10^{5} \mathrm{yr}$ after the initiation of the deposition of the trench-fill turbidites.

A second perhaps more plausible solution is that at least for $3 \times$ $10^{5} \mathrm{yr}$, a low $\mathrm{Cl}^{-}$fluid has been actively flowing below the décollement, at the horizon of the $\mathrm{Cl}^{-}$concentration minimum (and also possibly in the upper oceanic basement?), and advecting to the $\sim 820$ mbsf level.

Mixing between two active fluid flow systems of distinct sources, one at the $\mathrm{Cl}^{-}$concentration minimum horizon below the décollement, the other centered at the lithologic boundary between the upper and lower Shikoku Basin members, is a third possibility. The isotopic and geochemical evidence discussed below lends support to the latter two-tier fluid flow system.

\section{ISOTOPIC AND GEOCHEMICAL EVIDENCE FOR FLUID FLOW AND SOURCES}

\section{Methods}

A detailed discussion of the materials analyzed and methods used is given in Kastner and Elderfield (1992).

\section{Strontium Isotopes}

The six most conspicuous and important features that characterize the $\mathrm{Sr}$ isotope data, shown in Figure 5, are:

1. There is a distinct non-steady-state nature of the depth profile.

2. The ${ }^{87} \mathrm{Sr} /{ }^{86} \mathrm{Sr}$ ratio of even the shallowest pore-fluid sample analyzed, at $23 \mathrm{mbsf}$, is already considerably lower than the contemporaneous seawater with ${ }^{87} \mathrm{Sr} /{ }^{86} \mathrm{Sr}$ of 0.70916 .

3. No $\mathrm{Sr}$ isotope anomaly is observed at the décollement zone. Instead, a pronounced minimum in the ${ }^{87} \mathrm{Sr} /{ }^{86} \mathrm{Sr}$ ratio is located at $\sim 820$ mbsf, the depth that marks the boundary between the volcanicrich and -poor members of the Shikoku Basin sediments.

4. Below this minimum, the ${ }^{87} \mathrm{Sr} /{ }^{86} \mathrm{Sr}$ ratios increase steeply with depth, the greater the depth (the age of the sediment) the more radiogenic the ratios are. In contrast, the ${ }^{87} \mathrm{Sr} /{ }^{86} \mathrm{Sr}$ ratios of the seawater curve of middle to late Miocene, the age of the coexisting sediments at this depth range, decrease with increasing age (Burke et al., 1982).

5. A sharp reversal in the ${ }^{87} \mathrm{Sr} /{ }^{86} \mathrm{Sr}$ ratios, which occurs in the basal volcanic unit overlying oceanic basement, coincides with the strong increase in the $\mathrm{Cl}^{-}$concentration, most probably due to rapid smectite and zeolite authigenesis in the basal volcanic section at the prevailing high temperature of $\geq 120^{\circ} \mathrm{C}$.

6. The ${ }^{87} \mathrm{Sr}{ }^{86} \mathrm{Sr}$ ratio and $\mathrm{Cl}^{-}$concentration depth profiles appear to be decoupled (Fig. 5).

Evaluations of possible fluid sources may be aided through a mixing diagram between $\mathrm{Sr}$ isotopic compositions and $\mathrm{Sr}^{2+}$ concentrations of the pore fluids (Fig. 6). In such a diagram, two end-member mixing is described by a straight line. The data for Site 808 clearly show mixing of more than two fluid sources (Fig. 6). There seem to be three distinct end-member fluids, exclusive of the datum horizon at $23 \mathrm{mbsf}$ that has lower than seawater $\mathrm{Sr}^{2+}$ concentrations, possibly caused by the precipitation of a Sr-rich phase, i.e., the $\mathrm{CaCO}_{3} \cdot 6 \mathrm{H}_{2} \mathrm{O}$, ikaite, and the $\mathrm{Fe}$-phosphate, vivianite, we identified in the upper trench-fill turbidites. Interestingly, vivianite is a typical nonmarine diagenetic mineral; the significance of its occurrence in this section

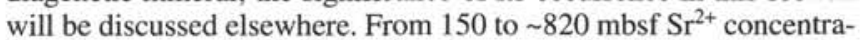
tions increase and ${ }^{87} \mathrm{Sr} /{ }^{86} \mathrm{Sr}$ ratios decrease with depth. Below, between 820 and $1240 \mathrm{mbsf}$, the $\mathrm{Sr}^{2+}$ concentrations are almost constant with depth $(250 \pm 50 \mu \mathrm{M}$, Tables 1 and 2$)$, but the ${ }^{87} \mathrm{Sr} /{ }^{86} \mathrm{Sr}$ ratios increase steadily and dramatically, indicative of a different fluid source, which is $\mathrm{Sr}^{2+}$-rich and highly radiogenic, a probably terrigenous continental source. The deepest sample analyzed (Fig. 5) indicates mixing with a third fluid source, $\mathrm{Sr}^{2+}$-rich and $\mathrm{Sr}$-isotopically nonradiogenic, probably an arc volcanic or oceanic basement source.

Depth profiles that gradually decrease in $\mathrm{Sr}$ isotopic ratios and increase in $\mathrm{Sr}^{2+}$ concentrations, as observed at 150-820 mbsf (Fig. 5), are common in marine sediment sections and have been attributed to volcanic matter alteration processes and/or carbonate recrystallization (Elderfield and Gieskes, 1982). At Site 808, volcanic ash is abundant above $\sim 820 \mathrm{mbsf}$ and below $\sim 1240 \mathrm{mbsf}$, and the overall carbonate content is $<5 \mathrm{wt} \%$. Therefore, at this site the former reaction is the more likely one to control the ${ }^{87} \mathrm{Sr} /{ }^{86} \mathrm{Sr}$ composition and $\mathrm{Sr}^{2+}$ 
A

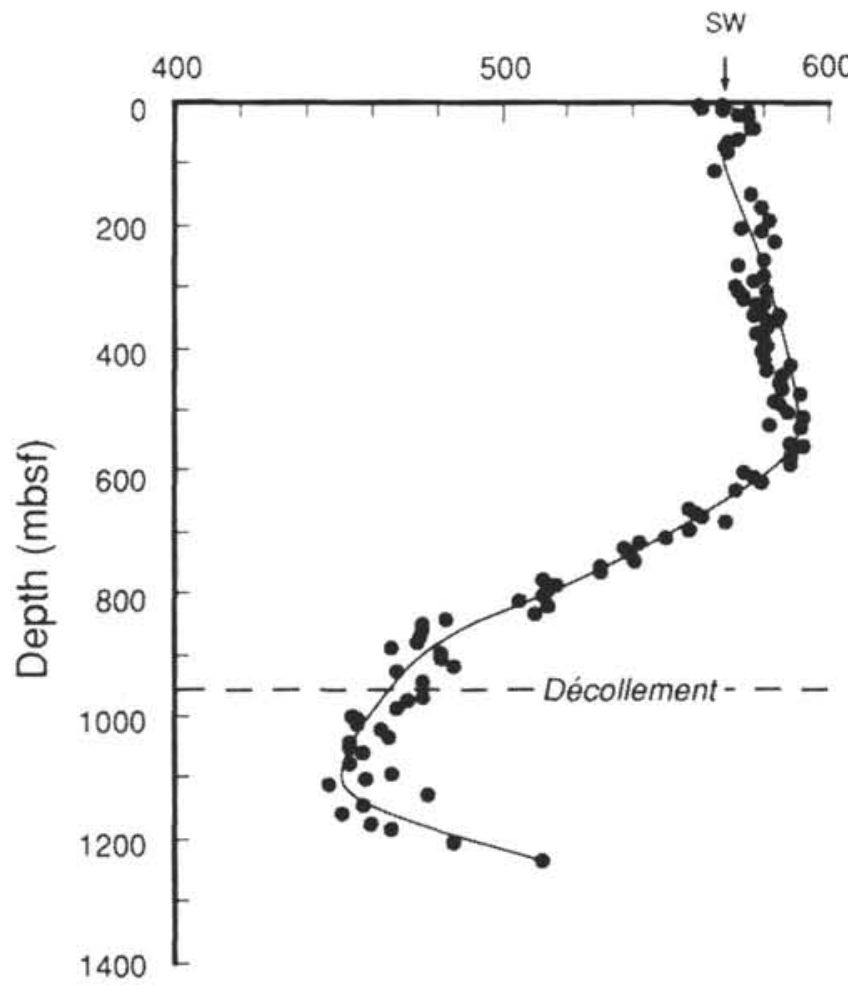

B

${ }^{87} \mathrm{Sr} /{ }^{86} \mathrm{Sr}$

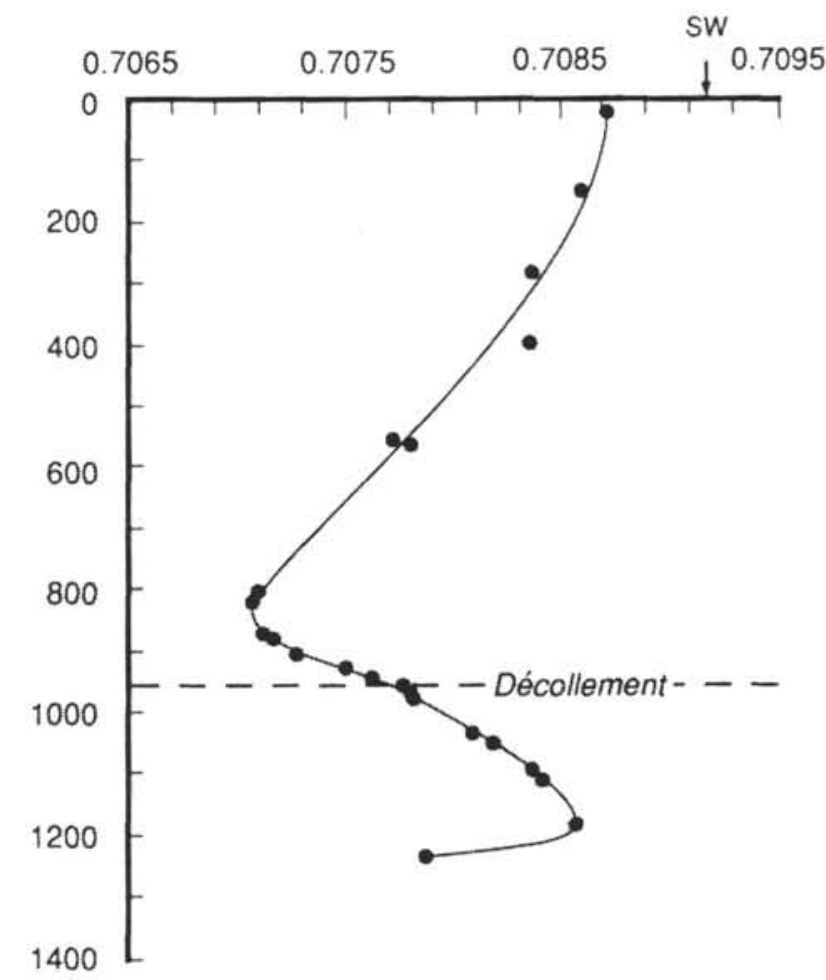

Figure 5. Depth profiles of (A) $\mathrm{Cl}^{-}$concentrations, and (B) ${ }^{87} \mathrm{Sr} /{ }^{86} \mathrm{Sr}$ ratios, of the pore fluids, Site 808 . The modern seawater (SW) values are marked by the arrows.

concentration values of pore fluid. Volcanic ash alteration to clay minerals and zeolites, however, consumes $\mathrm{H}_{2} \mathrm{O}$, as indeed reflected in the elevated $\mathrm{Cl}^{-}$concentrations above $560 \mathrm{mbsf}$ and below $>1200$ mbsf (Fig. 5). The steeper positive slope of the $\mathrm{Cl}^{-}$profile at $>1240$ than at $<560 \mathrm{mbsf}$ is attributed to temperatures, $>120^{\circ} \mathrm{C}$, at $1240 \mathrm{mbsf}$, whereas above $560 \mathrm{mbsf}$, temperatures are $<50^{\circ} \mathrm{C}$. A $10^{\circ} \mathrm{C}$ temperature increase approximately doubles the rates of these volcanic ash alteration reactions.

However, between 560 and 820 mbsf, within the volcanic-rich member of the Shikoku Basin sediments (Underwood et al., 1992), where the ${ }^{87} \mathrm{Sr} /{ }^{86} \mathrm{Sr}$ ratios of the pore fluids continue to decrease and the $\mathrm{Sr}^{2+}$ concentrations to increase, the trend of the $\mathrm{Cl}^{-}$concentrations profile reverses itself. The $\mathrm{Cl}^{-}$values decrease with depth rather than increase. The possibility of in-situ production of $\mathrm{H}_{2} \mathrm{O}$ to cause this $\mathrm{Cl}^{-}$ dilution, has been excluded in the above discussion. The only likely source of a fluid with nonradiogenic $\mathrm{Sr}$ composition, higher than seawater $\mathrm{Sr}^{2+}$, but low $\mathrm{Cl}^{-}$concentrations, is a fluid derived from dehydration and transformation reactions of clay minerals and zeolites, originally formed from volcanic materials. The source of such a fluid is hypothesized to lie arcward of Site 808.

Both (1) advective flow along the décollement and lower section of the frontal thrust and lateral migration of this fluid centered at this lithological boundary, at $\sim 820 \mathrm{mbsf}$ (and diffusive mixing between it and the diagenetic fluid at $560 \mathrm{mbsf}$ ), or (2) lateral fluid migration throughout the $560-820 \mathrm{mbsf}$ depth interval, at variable rates and fluid mixing ratios, but with the most intensive flow at the $\sim 820 \mathrm{mbsf}$ horizon, are consistent with the ${ }^{87} \mathrm{Sr} /{ }^{86} \mathrm{Sr}$ ratios and $\mathrm{Cl}^{-}$depth profiles in Figure 5.

What processes are responsible for the reversal of the $\mathrm{Sr}$ isotopic ratios gradient below 820 mbsf, within the non-volcanic lower member of the Shikoku Basin sediments? The $\mathrm{Sr}$ isotopic profile in this zone suggests mixing between two fluids, between the overlying fluid at $\sim 820 \mathrm{mbsf}$, of low $\mathrm{Cl}^{-}$and nonradiogenic $\mathrm{Sr}$ isotopic composition, as discussed above, and a fluid derived from a deep-seated source characterized by even a lower $\mathrm{Cl}^{-}$concentration but with a strong,

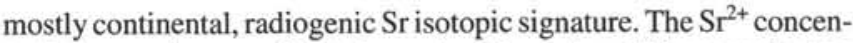
trations remain approximately constant throughout this zone; the two fluids must have similar $\mathrm{Sr}^{2+}$ concentrations. The pressure gradient does not promote downward mixing between the two fluids.

The most obvious source of this latter, deep-seated fluid is in the zone of underplating, of intense illitization of the subducted lower Shikoku Basin, and basal volcanic smectites, located arcward at a 4-6 km depth (A. Taira, pers. comm., 1992). There, high temperatures $\left(>100^{\circ} \mathrm{C}\right)$ prevail, and fluid-rock reactions, predominately the transformation of $\mathrm{S} \rightarrow \mathrm{I}$, hence $\mathrm{H}_{2} \mathrm{O}$ production, must be pervasive. Unlike in the upper member of the Shikoku Basin, where dehydration and transformation of "volcanic" clay minerals dominate the chemi$\mathrm{cal}$ and isotopic compositions of the fluid, in the lower member of the Shikoku Basin sediments, the transforming clay minerals are predominantly detrital and have a highly radiogenic, continental, $\mathrm{Sr}$ composition. Two bulk sediment samples, from the base of the lower member of the Shikoku Basin sediment, were analyzed for their ${ }^{87} \mathrm{Sr} /{ }^{86} \mathrm{Sr}$ isotopic ratios. The results, given in Tables 1 and 2 , show that these terrigenous sediments are indeed highly radiogenic, with ${ }^{87} \mathrm{Sr} /{ }^{86} \mathrm{Sr}$ values of 0.715178 and 0.715663 at 1185 and $1234 \mathrm{mbsf}$, respectively. At Site 808 , in-situ alteration of the basal volcaniclastics to clay minerals and zeolites is extensive, as indicated by the reversals of most chemical and isotopic profiles (Figs. 4, 5, 6). These subducted "volcanic: hydrous phases will as well dehydrate and the smectite will transform to illite, thus enhancing the $\mathrm{Cl}^{-}$dilution obtained from the terrigenous clay reactions but buffering the ${ }^{87} \mathrm{Sr} /{ }^{86} \mathrm{Sr}$ ratio of the fluid, as indeed observed. For example, a mixture of $40 \%$ radiogenic terrigenous $\mathrm{Sr}\left({ }^{87} \mathrm{Sr} /{ }^{86} \mathrm{Sr}\right.$ ratio of 0.715663$)$ with $60 \%$ andesitic-dacitic volcanic $\mathrm{Sr}\left({ }^{87} \mathrm{Sr} /{ }^{86} \mathrm{Sr}\right.$ ratio of $\left.0.704-0.705\right)$, provides the ${ }^{87} \mathrm{Sr}{ }^{86} \mathrm{Sr}$ ratios obtained for the lower Shikoku Basin pore fluids (i.e., ${ }^{87} \mathrm{Sr} /{ }^{86} \mathrm{Sr}$ values of $0.708563-0.707891$, Tables 1 and 2). The Sr concentrations of terrigenous and andesitic clays may be similar.

This deep-seated low $\mathrm{Cl}^{-}$fluid with its characteristic radiogenic $\mathrm{Sr}$ isotopic composition, is expelled tectonically, and migrates sea- 


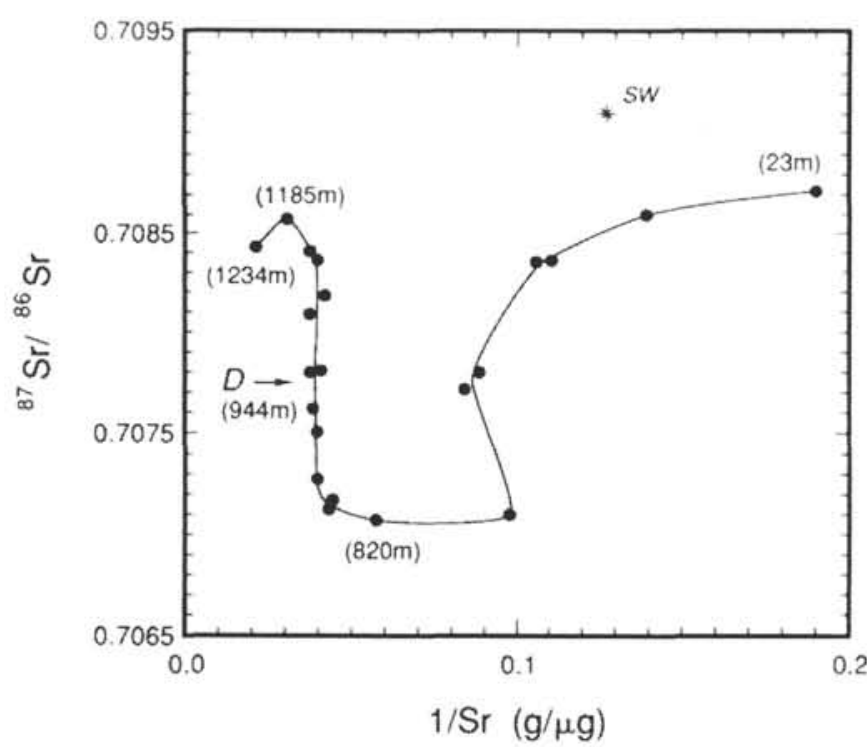

Figure 6. Mixing relationships between ${ }^{87} \mathrm{Sr} /{ }^{86} \mathrm{Sr}$ ratios and $1 / \mathrm{Sr}$ concentrations $(\mathrm{g} / \mu \mathrm{g})$, at Site 808 . The numbers in brackets indicate burial depths, and the arrows mark modern seawater compositions and the décollement (D).

ward beneath the décollement, and as indicated by the geochemical profiles, is transported mostly within the lower Shikoku Basin sediments. The basal volcanic section, which is highly altered, may be more impermeable, thus slowing or blocking fluid flow and having its unique geochemical signature. Some of this fluid may as well be migrating seaward through the upper oceanic basement. Formation fluids from basaltic oceanic crust were not recovered during Leg 131; therefore this possibility could not be verified. The lateral and vertical migration of this fluid through the subducted lower Shikoku Basin sediments is responsible for the distinct $\mathrm{Sr}$ isotopic and $\mathrm{Cl}^{-}$concentration gradients observed between $\sim 1240$ and $820 \mathrm{mbsf}$, in Figures 5 and 6 and for most of the other chemical anomalies observed across the décollement (Fig. 4).

This fluid flow regime below the dynamically sealed décollement is most probably responsible for the porosity increase and chemical discontinuities across the décollement, and for the high pore pressure in this zone. A steady-state between lateral and vertical fluid drainage and recharge through fluid flow seems to exist below the décollement.

\section{Sulfate Concentrations}

The sulfate concentration depth profile, shown in Figure 7, is particularly revealing concerning the origin of the fluid below the décollement. It indicates that sulfate reduction at Site 808 is complete below $\sim 6 \mathrm{mbsf}$, and that no sulfate is present between 6 and $820 \mathrm{mbsf}$. It also indicates that sulfate reduction in the Shikoku Basin sediments was incomplete; the bacterially mediated reaction became arrested when these sediments were subducted beneath the tip of the décollement; as the burial temperature increased, bacterial activity ceased. For inorganic sulfate reduction, temperatures of $\geq 250^{\circ} \mathrm{C}$ are required. Consequently, the subducted Shikoku Basin pore fluids contain a mixture of 6-8 $\mathrm{mM} \mathrm{SO}_{4} 2-$ and probably sulfide from sulfate reduction; the sulfate-sulfide content within the deep-seated fluid, transported seaward beneath the décollement, must be identical to these Shikoku Basin pore fluids. Sulfate diffusion and/or advection through the décollement, to $820 \mathrm{mbsf}$, may have been driven by the elevated sulfate concentrations and high pore pressures beneath the décollement. The 820-mbsf "barrier" for sulfate diffusion or advection (Fig. 7) may be controlled either bacterially or physically by the lateral fluid flow at this horizon. At $\sim 820 \mathrm{mbsf}$, the extrapolated
Table 1. Chemical and $\mathrm{Sr}$ isotopic compositions of pore fluids from the Nankai trough, Site 808.

\begin{tabular}{lccccc}
\hline $\begin{array}{c}\text { Core, section, } \\
\text { interval (cm) }\end{array}$ & $\begin{array}{c}\text { Depth } \\
(\mathrm{mbs})\end{array}$ & $\begin{array}{c}\mathrm{Cl} \\
(\mathrm{mM})\end{array}$ & $\begin{array}{c}\mathrm{Sr} \\
(\mu \mathrm{M})\end{array}$ & $\left.{ }^{87} \mathrm{Sr}\right)^{86} \mathrm{Sr}$ & $\sigma$ \\
\hline 131-808C- & & & & & \\
3H-5, 140-150 & 23 & 572 & 60 & 0.708711 & 22 \\
5X-1, 88-103 & 151 & 576 & 82 & 0.708592 & 20 \\
19X-1, 135-150 & 284 & 580 & 103 & 0.708367 & 29 \\
11R-2, 50-63 & 397 & 581 & 107 & 0.708348 & 18 \\
27R-5, 123-150 & 557 & 588 & 135 & 0.707723 & 21 \\
28R-2, 124-150 & 562 & 592 & 129 & 0.707797 & 22 \\
53R-4, 120-150 & 805 & 512 & 116 & 0.707099 & 23 \\
55R-2, 120-150 & 822 & 514 & 202 & 0.707069 & 16 \\
60R-4, 116-150 & 873 & 475 & 262 & 0.707121 & 16 \\
61R-2, 115-150 & 879 & 474 & 258 & 0.707164 & 16 \\
64R-1, 115-150 & 907 & 481 & 282 & 0.707281 & 20 \\
66R-2, 115-150 & 928 & 468 & 284 & 0.707499 & 22 \\
68R-1, 5-10 & 944 & 476 & 298 & 0.707622 & 20 \\
"69R-1, composite sample & $954-963$ & - & - & 0.707764 & 18 \\
70R-4, 0-35 & 968 & 476 & 302 & 0.707798 & 21 \\
71R-2, 120-150 & 976 & 471 & 277 & 0.707812 & 18 \\
77R-4, 0-35 & 1035 & 465 & 302 & 0.708084 & 21 \\
79R-2, 0-35 & 1050 & 453 & 271 & 0.708183 & 18 \\
84R-1, 120-150 & 1093 & 466 & 283 & 0.708370 & 24 \\
86R-2, 115-150 & 1109 & 447 & 299 & 0.708408 & 16 \\
b4R-1, 0-35 & 1185 & 466 & 372 & 0.708563 & 17 \\
99R-1, 0-30 & 1234 & 512 & 500 & 0.707891 & 16 \\
\hline
\end{tabular}

a Wash with ultrapure water of carefully cleaned composite sample

${ }^{\mathrm{b}}$ Solid residue 0.715178 (17).

${ }^{c}$ Solid residue 0.715663 (18).

temperature, assuming a linear geothermal gradient of $110^{\circ} \mathrm{C} / \mathrm{km}$, is $\sim 90^{\circ} \mathrm{C}$, which is approximately the maximum temperature for bacterial sulfate reduction. It thus is possible that sulfate-reducing bacteria regulate the sulfate diffusion-advection depth; the alkalinity concentration profile (Taira, Hill, Firth, et al, 1991; Gieskes et al, 1992) is consistent with such an interpretation.

\section{Oxygen and Hydrogen Isotopes}

The depth profiles of $\mathrm{O}$ and $\mathrm{H}$ isotopes, shown in Figure 8, are compatible with the two-tier lateral fluid flow regime discussed in the Sr-isotopes chapter.

Overall, in the Shikoku Basin sediments, the oxygen isotopic ratios of the pore fluids become enriched in ${ }^{18} \mathrm{O}$ and depleted in $\mathrm{D}$ with depth, particularly below the décollement, which is typical for diagenetic systems with extensive fluid-rock interactions, especially of the $\mathrm{S} \rightarrow \mathrm{I}$ transformation reaction (i.e., Moum and Rosenqvist, 1958; Savin and Epstein, 1970; Suchecki and Land, 1983; Savin and Lee, 1988; Primmer and Shaw, 1991, and references therein). The $\mathrm{O}$ and $\mathrm{H}$ isotope profiles are not coupled throughout, because the oxygen is also involved, independently of hydrogen, in anhydrous phase reactions, and the hydrogen is strongly influenced by organic matter decomposition reactions.

In the trench-fill turbidites section, hydration reactions are responsible for the observed depleted $\delta^{18} \mathrm{O}$ values, of $-2 \%$ to $-3 \%$ (SMOW, Craig, 1961) (Fig. 8 and Table 3). But the pore-fluid hydrogen does not show the expected increase in $\delta \mathrm{D}$ values from hydration reactions; instead, its $\delta \mathrm{D}$ becomes lighter, because in this depth interval hydrogen is primarily involved in organic matter reactions.

At $\sim 820 \mathrm{mbsf}$ the very small but distinct inverse shift in the $\delta^{18} \mathrm{O}$ and $\delta \mathrm{D}$ values, toward enrichment in ${ }^{18} \mathrm{O}$ and depletion in $\mathrm{D}$, indicates communication with a diagenetically more evolved fluid. Below the décollement the opposite shifts in the $\delta^{18} \mathrm{O}$ and $\delta \mathrm{D}$ values are considerably more extreme, suggesting mixing with a highly evolved fluid. The most likely source of such a fluid is from the $S \rightarrow I$ reaction, which reaches completion at elevated temperatures of $\geq 120^{\circ} \mathrm{C}$, the prevailing temperature in the deeper arcward zone of underplating. 
Table 2. $\mathrm{Sr}$ isotopic ratios and concentrations of pore fluids from the Nankai trough, Site 808.

\begin{tabular}{|c|c|c|c|c|c|c|c|}
\hline $\begin{array}{l}\text { Core. section. } \\
\text { interval }(\mathrm{cm})\end{array}$ & $\begin{array}{l}\text { Depth } \\
\text { (mbsf) }\end{array}$ & ${ }^{x 7} \mathrm{Sr} r^{x / 6} \mathrm{Sr}$ & $\sigma$ & $\begin{array}{l}\mathrm{Sr}^{2} \\
(\mu \mathrm{M})\end{array}$ & $\begin{array}{c}\mathrm{Sr}^{b} \\
(\mu \mathrm{M})\end{array}$ & $1 / S r^{c}$ & $1 / \mathrm{Sr}^{d}$ \\
\hline \multicolumn{8}{|l|}{$131-808 \mathrm{C}$ - } \\
\hline $3 \mathrm{H}-5,140-150$ & 23 & 0.708711 & 22 & 60 & 60 & 0.0167 & 0.0167 \\
\hline $5 X-1.88-103$ & 151 & 0.708592 & 20 & 82 & ('83) & 0.0122 & $(0.0120)$ \\
\hline $19 \mathrm{X}-1.135-150$ & 284 & 0.708367 & 29 & 103 & (103) & 0.0097 & $(0.0097)$ \\
\hline IIR-2. 50-63 & 397 & 0.708348 & 18 & 107 & 107 & 0.0093 & 0.0093 \\
\hline $27 R-5,12,3-150$ & 557 & 0.707723 & 21 & 135 & 135 & 0.0074 & 0.0074 \\
\hline $28 R-2.124-150$ & 562 & 0.707797 & 22 & 129 & (151) & 0.0078 & (0.0066) \\
\hline $53 R-4,120-150$ & 805 & 0,707099 & 23 & 116 & (108) & 0.0086 & (0.0093) \\
\hline $55 R \cdot 2.120-150$ & 822 & 0.707069 & 16 & 202 & 202 & 0.0050 & 0.0050 \\
\hline $60 R-4,116-150$ & 873 & 0.707121 & 16 & 262 & 262 & 0.0038 & 0.0038 \\
\hline GIR-2.115-150 & 879 & 0.707164 & 16 & 258 & 258 & 0.0039 & 0.0039 \\
\hline $64 R-1.115-150$ & 907 & 0.707281 & 20 & 282 & 282 & 0.0035 & 0.0035 \\
\hline $66 R-2.115-150$ & 928 & 0.707499 & 22 & 284 & 284 & 0.0035 & 0.0035 \\
\hline $68 \mathrm{R}-1.5-10$ & 944 & 0.707622 & 20 & 298 & (325) & 0.0034 & $(0.0031)$ \\
\hline 69R-1. composite sample & $954-963$ & 0.707764 & 18 & - & - & - & - \\
\hline $70 R-4.0-35$ & 968 & 0.707798 & 21 & 302 & 302 & 0.0033 & 0.0033 \\
\hline $71 \mathrm{R} \cdot 2.120-150$ & 976 & 0.707812 & 18 & 277 & 277 & 0.0036 & 0.0036 \\
\hline $77 R \cdot 4 \cdot 0-35$ & 1035 & 0.708084 & 21 & 302 & 302 & 0.0033 & 0.0033 \\
\hline $79 R-2.0-35$ & 1050 & 0.708183 & 18 & 271 & 271 & 0.0037 & 0.0037 \\
\hline $84 R-1.120-150$ & 1093 & 0.708370 & 24 & 283 & 283 & 0.0035 & 0.0035 \\
\hline $86 R-2,115-150$ & 1109 & 0.708408 & 16 & 299 & 299 & 0.0033 & 0.0033 \\
\hline $94 \mathrm{R}-1.0-35$ & 1185 & 0.708563 & 17 & 372 & 372 & 0.0027 & 0.0027 \\
\hline $899 R-1,0-30$ & 1234 & 0.707891 & 16 & 500 & 500 & 0.0020 & 0.0020 \\
\hline
\end{tabular}

"Values from atomic absorption measurements.

${ }^{b}$ Values from atomic absorption measurements except for values in bold numbers. measured by isotope dilution.

Calculated from concentration values measured by atomic absorption

Calculated from concentration values measured by atomic absorption and isotope dilution.

ETe concentrations in bold numbers were analyzed by isotope dilution, the rest by atomic absorption.

Solid residue $\mathrm{x}^{\mathrm{x}} \mathrm{Sr} / \mathrm{r}^{\mathrm{kn}} \mathrm{Sr}$ ratio: $0.715178(17)$.

Folid residue ${ }^{x / 8} \mathrm{Sr} /{ }^{\mathrm{xt}} \mathrm{Sr}$ ratio: 0.715663 (18).

In this subduction system this occurs at $4-6 \mathrm{~km}$ depth (A. Taira, pers. comm., 1992). There, pore-space reduction and clay transformation reactions are intense.

Smectite dehydration alone would not be able to produce these strong inverse isotopic signals because the interlayer water in smectite exchanges continuously with the pore fluids, thus reflecting them (Moum and Rosenqvist, 1958; Savin and Epstein, 1970; Primmer and Shaw, 1991). The residual diagenetically evolved fluid from the $\mathrm{S} \rightarrow \mathrm{I}$ reaction, which is enriched in ${ }^{18} \mathrm{O}$ and depleted in $\mathrm{D}$, upon advection and transport into shallower levels of the system may become involved in smectite reactions.

In the lower member of the Shikoku Basin sediments the pore fluid oxygen isotopic composition profile (Fig. 8) mimics the profile of the ${ }^{87} \mathrm{Sr} /{ }^{86} \mathrm{Sr}$ ratios (Fig. 5). Both reflect the same deep-seated seaward migrating fluid.

The origin of the enrichment in D observed at 1111 mbsf (Fig. 8) is as yet unknown, but may be related to solid reactions within the zone between 1085-1115 mbsf, in which significant bulk solid chemical anomalies were encountered (Underwood et al., this volume). Preliminary mineralogical work indicates the presence of apatite, rhodochrosite, barite, and pyrite in this zone and rather abundant anatase and rutile. The origin of this chemically and mineralogically "anomalous" horizon is as yet unknown. If the origin was or is hydrothermal, it may have evolved early while near the ridge-crest, or may now be forming from the deep-seated migrating fluid.

Long-distance lateral migration of a low- $\mathrm{Cl}^{-}$and ${ }^{18} \mathrm{O}$-enriched fluid, derived at elevated temperatures from the $\mathrm{S} \rightarrow \mathrm{I}$ transformation reaction, was invoked by Vrolijk et al. (1991) in the Barbados subduction zone. There, however the fluid migrates laterally along the décollement and other active faults; at the western Nankai subduction zone it migrates diffusively seaward beneath the décollement.

In light of the distinct pore-fluid $\delta \mathrm{D}$ vs. $\delta^{18} \mathrm{O}$ plots for the Barbados and Nankai systems displayed in Figure 9, the assumption that the actively migrating fluids have the same origin at both subduction zones, is puzzling. The sources of helium in these two subduction zones are also distinct.

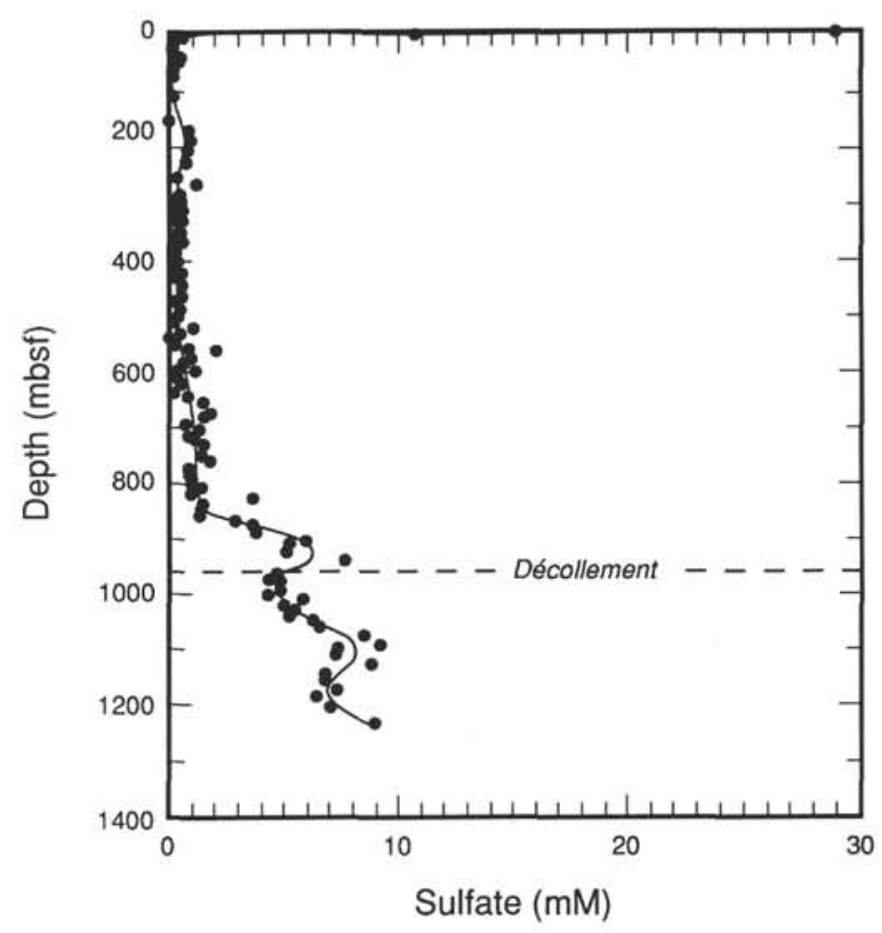

Figure 7. Depth profile of sulfate concentrations $(\mathrm{mM})$ in interstitial fluids, Site 808 .

\section{He Isotopes}

Helium is an excellent geochemical tracer because it is conservative, unaffected by chemical reactions, and hence uniquely defines its source.

From the seven samples collected for He isotope analyses, three were seriously air-contaminated. The remaining four samples were analyzed for $\mathrm{He}$ and $\mathrm{Ne}$ concentrations and for $\mathrm{He}$ isotopes. The uncertainty in the $\mathrm{He}$ isotopic ratios is approximately $0.004 \mathrm{R} / \mathrm{Ra}$ and in the He concentration $0.4 \mathrm{ncm}^{3} / \mathrm{g}$; the main contribution to the errors is the uncertainty in the "ambient" values. (The He isotopic results are reported as a ratio relative to the atmospheric ratio, $\mathrm{Ra}$; the upper mantle value is $8 \mathrm{Ra}$ ). The results are shown in Figure 10. The range in $\mathrm{He}$ isotopic ratios is from a continental/radiogenic value in the shallower two samples, with $\mathrm{R} / \mathrm{Ra}$ of 0.616 and 0.523 , respectively, to increasing mantle contribution with depth. The $\mathrm{R} / \mathrm{Ra}$ ratio of the deepest sample analyzed, below the décollement, of 1.915 , indicates $\sim 25 \%$ mantle contribution. The He concentrations also increase with depth, from 79.31 to $138.6 \mathrm{ncm}^{3} / \mathrm{g}$, hence excluding the possibility that the depth increase in the ${ }^{3} \mathrm{He} /{ }^{4} \mathrm{He}$ ratios is caused by ${ }^{4} \mathrm{He}$ loss. Poreda et al. (1988) observed a range of mantle He contribution in six other subduction zones, i.e., in Taiwan, New Zealand, the Philippines, Indonesia, Thailand, and Alaska, with R/Ra values from 0.5 to 3.8. Only at the Barbados subduction zone the gases do not contain mantle $\mathrm{He}$; the $\mathrm{He}$ in the Barbados subduction zone is completely of crustal origin (Poreda et al., 1988).

The presence of a mantle $\mathrm{He}$ contribution is usually indicative of active volcanism. But in the absence of this direct input mantle $\mathrm{He}$ source, transport through hydrothermal fluids that have "swept-up" mantle He, as suggested by Poreda et al. (1988), is a most likely alternative. Active faults are the most likely conduits for mantle He migration. From the profile in Figure 10, it appears that at Nankai the décollement is not the conduit for mantle $\mathrm{He}$; the sample below the décollement has the highest mantle He contribution, probably reflecting the advective component of the hot fluid regime below the décollement. 

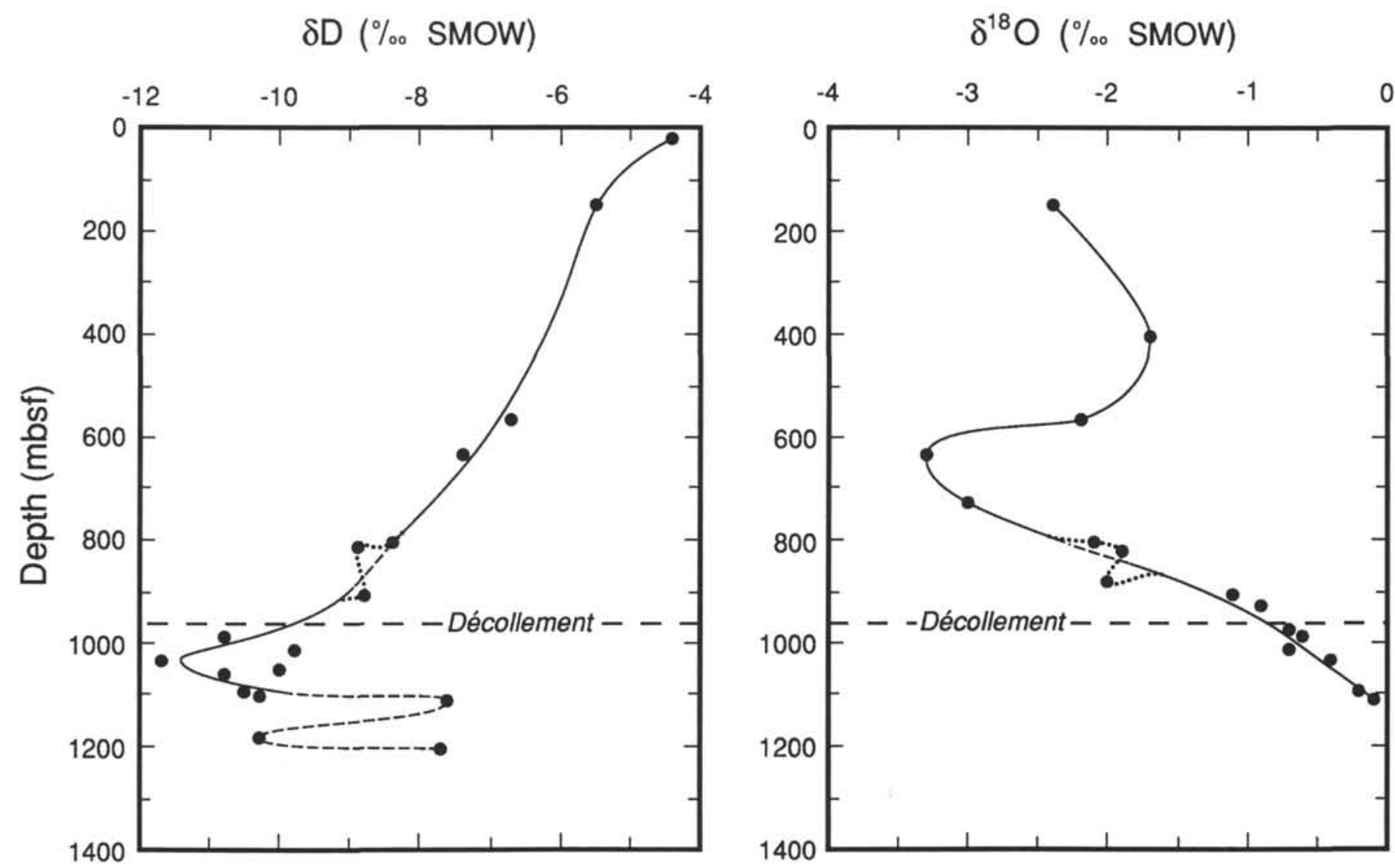

Figure 8. Depth profiles of oxygen and hydrogen isotopic ratios (\%o SMOW), in pore fluids at Site 808.

\section{MINERALIZED VEINS AND TUBULAR-CYLINDRICAL STRUCTURES}

Mineralized veins and tubular-cylindrical vein-like structures are common in the sediments of the lower member of the Shikoku Basin sediments, from $\sim 820$ to $\sim 1240 \mathrm{mbsf}$. In addition, Mg-rich calcite that contains $\sim 6$ mole $\% \mathrm{MgCO}_{3}$ line the numerous slickenside surfaces. The same $\mathrm{Mg}$-calcite is the dominant mineral in the microveins analyzed. The oxygen isotope ratios of these calcites, given in Table 4, indicate formation at elevated temperatures, between $100^{\circ}$ and $120^{\circ} \mathrm{C}$, consistent with present in-situ temperatures, assuming a $110^{\circ} \mathrm{C} / \mathrm{km}$ geothermal gradient. This calculation is based on the O'Neil et al. (1969) experimentally determined calcite-water ${ }^{18} \mathrm{O} /{ }^{16} \mathrm{O}$ fractionation factor, and on the assumption that $\delta^{18} \mathrm{O} \mathrm{H}_{2} \mathrm{O}=0 \%$. This calculated temperature also agrees with the above-mentioned $\mathrm{Li}-\mathrm{Mg}$ geothermometer (Kharaka and Mariner, 1989). The carbon isotopic compositions indicate an advanced thermally degraded organic carbon source, discussed in detail in Gamo et al. (1992) and in Berner and Faber (1992).

The tubular-cylindrical vein-like structures, shown in Figure 11, are mineralogically zoned. The brown-red margins are enriched in Fe-Mn oxyhydroxides, the light-colored zone with intergrown elongated crystals consists mostly of gypsum and/or anhydrite; pyrite is the dominant mineral in the central dark gray to black zone. The source of the sulfate and sulfide in these mineralized features is the subducted Shikoku Basin pore fluid.

The most interesting and largest calcite vein was found at 1066 mbsf (Sample 131-808C-80R-CC, Table 4). It is $\sim 1.5 \mathrm{~cm}$ wide, and contains $0.1-0.4 \mathrm{~mm}$ dark gray clay inclusions, shown in Figure 12. The $\delta^{18} \mathrm{O}$ value of the calcite is $15.9 \%$ (SMOW) (Table 4), suggesting precipitation at $\sim 120^{\circ} \mathrm{C}$, the approximate in-situ temperature. The clay inclusions are mineralogically distinct from the matrix clay, composed of two end-members clay minerals, smectite with no illite interlayering and discrete illite. The $\delta^{18} \mathrm{O}$ value of the clay inclusions is $18.7 \%$ (SMOW), $2.5 \%$ heavier than the matrix clay minerals.

The temperature of formation of the inclusion clay minerals is not known because the porosity and $\delta^{18} \mathrm{O}$ values of the terrigenous unaltered clays and of the deep-seated fluid are not known. Clearly, based on its mineralogy and oxygen isotopes, the inclusions clay has not been trapped from the surrounding sediment. It must have been transported with the fluid from greater depth to the site of the calcite deposition, suggesting vigorous fluid flow. Importantly, the fact that the $\delta^{18} \mathrm{O}$ value of the clay in inclusions is higher than of the host calcite indicates that the calcite and clay minerals are not in isotopic equilibrium, that they did not precipitate from the same solution and/or at the same temperature. The calcite most probably precipitated at the in-situ temperature due to pressure and/or temperature release. It trapped the authigenic clay that formed either at lower temperatures or more likely from a water enriched in ${ }^{18} \mathrm{O}$ water, typically a highly evolved diagenetic fluid.

\section{THE FRONTAL THRUST}

Although no clear evidence for active fluid flow at the frontal thrust exists, leakage of heavy oxygen is suggested in Figure 8. Similarly, Berner and Faber (1992), based on the $\delta^{13} \mathrm{C}$ the organic matter gas profiles, suggest leakage of ethane and propane at the frontal thrust, with an origin at the décollement.

\section{SUMMARY AND CONCLUSIONS}

A schematic sketch of the fluid flow regime at the western Nankai trough is presented in Figure 13. The main conclusions which support this proposed hydrology are summarized below. 
Table 3. Oxygen and hydrogen isotopic compositions of pore fluids from the Nankai trough, Site 808.

\begin{tabular}{|c|c|c|c|c|c|}
\hline \multirow{2}{*}{$\begin{array}{l}\begin{array}{c}\text { Core, section, } \\
\text { interval }(\mathrm{cm})\end{array} \\
131-808 \mathrm{C} \text { - }\end{array}$} & \multirow[t]{2}{*}{$\begin{array}{l}\text { Depth } \\
\text { (mbsf) }\end{array}$} & \multicolumn{2}{|c|}{$\begin{array}{c}\delta^{18} \mathrm{O} \\
(\% \circ \text { SMOW })\end{array}$} & \multicolumn{2}{|c|}{$\begin{array}{c}\delta \mathrm{D} \\
(\% \circ \mathrm{SMOW})\end{array}$} \\
\hline & & & & & \\
\hline $3 \mathrm{H}-5,140-150$ & 23 & & & -4.4 & \\
\hline $5 X-1,88-103$ & 151 & -2.5 & ${ }^{\mathrm{a}}-2.3$ & -5.7 & a -5.4 \\
\hline $12 \mathrm{R}-1,130-150$ & 406 & -1.7 & & & \\
\hline $28 \mathrm{R}-4,110-150$ & 565 & -2.2 & a -2.2 & & a -6.7 \\
\hline $35 \mathrm{R}-4,132-150$ & 632 & -3.3 & & -7.2 & -7.6 \\
\hline $45 \mathrm{R}-4,125-150$ & 728 & -3.0 & & & \\
\hline $53 \mathrm{R}-4,120-150$ & 805 & -2.1 & & -7.5 , & -9.2 \\
\hline $54 \mathrm{R}-2,120-150$ & 812 & & & -8.9 & \\
\hline $55 \mathrm{R}-2,120-150$ & 822 & -1.9 & & & \\
\hline $61 R-2,115-150$ & 880 & -2.0 & & & \\
\hline $64 \mathrm{R}-1,115-150$ & 907 & & & -8.8 & \\
\hline $65 \mathrm{R}-2,0-34$ & 917 & -1.1 & & & \\
\hline $66 \mathrm{R}-2,115-150$ & 928 & -0.9 & & & \\
\hline $71 \mathrm{R}-2,120-150$ & 976 & -0.7 & & & \\
\hline $72 \mathrm{R}-3,0-5$ & 986 & & ${ }^{a}-0.6$ & -10.3 & a -11.3 \\
\hline $75 \mathrm{R}-1,117-145$ & 1013 & -0.7 & & -9.9 & -9.6 \\
\hline $77 \mathrm{R}-4,0-35$ & 1035 & -0.4 & & -11.7 & -11.6 \\
\hline $79 \mathrm{R}-2,0-35$ & 1050 & & & -10.0 & \\
\hline $80 \mathrm{R}-2,125-150$ & 1061 & & & -10.8 & -10.5 \\
\hline $84 \mathrm{R}-1,120-150$ & 1093 & -0.2 & & -10.4 & -10.6 \\
\hline $85 R-2,120-150$ & 1101 & & & -10.3 & \\
\hline $86 \mathrm{R}-2,115-150$ & 1111 & -0.1 & & -6.8 & -8.4 \\
\hline $94 \mathrm{R}-1,0-35$ & 1185 & & & -10.4 & -10.2 \\
\hline $96 \mathrm{R}-1,0-36$ & 1204 & & & -7.8 & -7.6 \\
\hline
\end{tabular}

${ }^{\text {a }}$ Data from Dr. S. Epstein's laboratory.

1. The chemical concentrations and isotope ratios depth profiles do not support active pervasive fluid flow either at the décollement zone or at the frontal thrust. They do, however, support pervasive active lateral fluid flow above and below the décollement.

2. Above the décollement, within the upper volcanic-rich member of the Shikoku Basin sediments, but most probably centered at $\sim 820 \mathrm{mbsf}$, lateral flow of a low $\mathrm{Cl}^{-},{ }^{18} \mathrm{O}$-rich, and $\mathrm{D}$-poor fluid with a nonradiogenic, oceanic or arc $\mathrm{Sr}$ isotopic signature, exists. Its origin is from authigenic "volcanic" hydrous minerals reactions.

3. Below the décollement, within the lower Shikoku Basin sediments, and most probably centered at its base (and possibly in the upper oceanic basement), active lateral and vertical flow of a low $\mathrm{Cl}^{-}$, ${ }^{18} \mathrm{O}$-rich, and D-poor fluid exists. It has a radiogenic terrigenous-continental Sr isotopic signature. Its source is arcward, within the deeplyburied subducted section, from illitization of a terrigenous plus authigenic "volcanic" smectite assemblage.

4. The fluid flow below the décollement must have been rather vigorous, capable of transporting authigenic clay minerals along great distances.

5. The discontinuities across the décollement in both the physical and the pore-fluid chemical profiles indicate that the décollement zone is highly overpressured, and acts as a leaky dynamic "barrier" for upward fluid flow.

6. The zone below the décollement is a high pore-pressure zone of no net drainage and exhibits distinct chemical signatures. A steadystate between lateral and vertical drainage and recharge through fluid flow, must exist below the décollement.

7. The absence of macroscopic mud-filled and mineralized faults, fractures and veins in this extensively faulted and fractured accretionary complex, especially in the décollement zone, but the presence of minor mineralization along microstructures and of mineralized microveins and tubular-cylindrical vein-like structures, is indicative of the pervasive mode of dewatering, which appears to be predominantly microchannelized diffuse, instead of macrochannelized, through major faults and other conspicuous tectonic features.

8. Advective transport of a hot fluid, in excess of the pore fluids internally available, is required to sustain the regional high HF.
9. Except for minor leakage of possibly ${ }^{18} \mathrm{O}$-rich water and of ethane and propane from the décollement, the lack of evidence for active fluid flow at the frontal thrust may be related to the youthfulness of the thrust.

\section{ACKNOWLEDGMENTS}

We are especially grateful to S.M. Savin for the oxygen isotope analyses of the clay mineral samples and to S. Epstein for the oxygen and hydrogen isotope pore-fluid duplicate analyses of three of the samples. Our discussions with Leg 131 scientists during and after the cruise were invaluable. The research was supported by the National Science Foundation through the United States Science Committee (JOI-USSAC) Program, the NSF Grant \#OCE92-03879 to M. Kastner, and by the National Environmental Research Council in the United Kingdom, to H. Elderfield.

\section{REFERENCES*}

Bangs, N.L.B., Westbrook, G.K., Ladd, J.W., and Buhl, P., 1990. Seismic velocities from the Barbados Ridge complex: indicators of high pore fluid pressures in an accretionary complex. J. Geophys. Res., 95:8767-8782.

Boulègue, J., Iiyama, J.T., Charleu, J.L., and Sewab, J., 1987. Nankai Trough, Japan Trench and Kuril trench: geochemistry of fluid samples by submersible "Nautile." Earth Planet. Sci. Lett., 83:362-375.

Bray, C.J., and Karig, D.E., 1985. Porosity of sediments in accretionary prisms, and some implications for dewatering processes. J. Geophys. Res., 90:768-778.

Brown, K., and Westbrook, G.K., 1988. Mud diapirism and subcretion in the Barbados Ridge accretionary complex: the role of fluids in accretionary processes. Tectonics, 7:613-640.

Burke, W.H., Denison, R.E., Hetherington, E.A., Koepnick, R.B., Nelson, H.F., and Otto, J.B., 1982. Variation of seawater ${ }^{87} \mathrm{Sr} /{ }^{86} \mathrm{Sr}$ throughout Phanerozoic time. Geology, 10:516-519.

Burst, J.F., 1969. Diagenesis of Gulf Coast clayey sediments and its possible relation to petroleum migration. AAPG Bull., 53:73-93.

Carson, B., 1977. Tectonically induced deformation of deep-sea sediments off Washington and northern Oregon: mechanical consolidation. Mar. Geol., 24:289-307.

Carson, B., Suess, E., and Strasser, J.C., 1990. Fluid flow and mass flux determinations at vent sites on the Cascadia margin accretionary prism. J. Geophys. Res., 95:8891-8898.

Chamley, H., Cadet, J.-P., and Charvet, J., 1986. Nankai Trough and Japan Trench Late Cenozoic paleoenvironments deduced from clay mineralogic data. In Kagami, H., Karig, D.E., Coulbourn, W.T., et al., Init. Repts. DSDP, 87: Washington (U.S. Govt. Printing Office), 633-641.

Claypool, G.E., and Kaplan, I.R., 1974. The origin and distribution of methane in marine sediments. In Kaplan, I.R. (Ed.), Natural Gases in Marine Sediments: New York (Plenum), 99-140.

Colten-Bradley, V.A., 1987. Role of pressure in smectite dehydration-effects on geopressure and smectite-to-illite transformation. AAPG Bull., 71:1414-1427.

COSOD II, 1987. Rep. 2nd Conf. Sci. Ocean Drilling, Strasbourg, France, (European Science Foundation).

Craig, H., 1961. Isotopic variations in meteoric waters. Science, 133:1702-1703.

Eberl, D., and Hower, J., 1976. Kinetics of illite formation. Geol. Soc. Am. Bull., 87:1326-1330.

Elderfield, H., and Gieskes, J.M., 1982. Sr isotopes in interstitial waters of marine sediments from Deep Sea Drilling Project cores. Nature, 300:493-497.

Elderfield, H., Kastner, M., and Martin, J.B., 1990. Composition and sources of fluids and sediments of the Peru subduction Zone. J. Geophys. Res., 95:8819-8827.

Fisher, A.T., and Hounslow, M.W., 1990. Transient fluid flow through the toe of the Barbados accretionary complex: constraints from Ocean Drilling Program Leg 110 heat flow studies and simple models. J. Geophys. Res., 95:8845-8858

* Abbreviations for names of organizations and publication titles in ODP reference lists follow the style given in Chemical Abstracts Service Source Index (published by American Chemical Society). 
Fisher, J.B., and Boles, J.R., 1990. Water-rock interaction in Tertiary sandstones, San Joaquin Basin, California, USA: diagenetic controls on water composition. Chem. Geol., 82:83-101.

Foucher, J.P., LePichon, X., Lallemant, S., Hobart, M.A., Henry, P., Benedetti, M., Westbrook, G.K., and Langseth, M.G., 1990. Heat flow, tectonics, and fluid circulation at the toe of the Barbados Ridge accretionary prism. J. Geophys. Res., 95:8859-8868.

Fowler, S.R., White, R.S., and Louden, K.E., 1985. Sediment dewatering in the Makran accretionary prism. Earth Planet. Sci. Lett., 75:427-438.

Freed, R.L., and Peacor, D.R., 1989. Variability in temperature of the smectite/illite reaction in Gulf Coast sediments. Clay Miner., 24:171-180.

Gieskes, J.M., Blanc, G., Vrolijk, P., Elderfield, H., and Barnes, R., 1990. Interstitial water chemistry - major constituents. In Moore, J.C., Mascle, A., et al., Proc. ODP, Sci. Results, 110: College Station, TX (Ocean Drilling Program), 155-178.

Hamilton, E.L., 1976. Variations of density and porosity with depth in deep-sea sediments. J. Sediment. Petrol., 46:280-300.

Han, M.W., and Suess, E., 1989. Subduction induced pore fluid venting and the formation of authigenic carbonates along the Cascadia continental margin: implications for the global Ca-cycle. Palaeogeogr., Palaeoclimatol., Palaeoecol., 71:97-118.

Henry, P., LePichon, X., Lallemant, S., Foucher, J.-P., Westbrook, G., and Hobart, M., 1990. Mud volcano field seaward of the Barbados accretionary complex: a deep-towed side scan sonar survey. J. Geophys. Res., 95:8917-8929.

Hower, J., Eslinger, E.V., Hower, M.E., and Perry, E.A., 1976. Mechanism of burial metamorphism of argillaceous sediment: mineralogical and chemical evidence. Geol. Soc. Am. Bull., 87:725-737.

Hyndman, R.D., Foucher, J.P., Yamano, M., Fisher, A., and Scientific Team of Ocean Drilling Program Leg 131, 1992. Deep sea bottom-simulation-reflectors: calibration of the base of the hydrate stability field as used for heat flow estimates. Earth Planet. Sci. Lett., 109:289-302.

Ingle, J.C., Jr., Karig, D.E., et al., 1975. Init. Repts. DSDP, 31: Washington (U.S. Govt. Printing Office).

Kagami, H., Karig, D.E., Coulbourn, W.T., et al., 1986. Init. Repts. DSDP, 87: Washington (U.S. Govt. Printing Office).

Karig, D.E., Moran, K., and Leg 131 Scientific Party, 1990. A dynamically sealed décollement: Nankai prism. Int. Conf. on Fluids in Subduction Zones, Paris.

Kastner, M., Elderfield, H., and Martin, J.B., 1991. Fluids in convergent margins: what do we know about their composition, origin, role in diagenesis and importance for oceanic chemical fluxes? Philos. Trans. R. Soc. London A, 335:243-259.

Kastner, M., Elderfield, H., Martin, J.B., Suess, E., Kvenvolden, K.A., and Garrison, R.E., 1990. Diagenesis and interstitial-water chemistry at the Peruvian continental margin - major constituents and strontium isotopes. In Suess, E., von Huene, R., et al., Proc. ODP, Sci. Results, 112: College Station, TX (Ocean Drilling Program), 413-440.

Kemp, A.E.S., 1990. Fluid flow in "vein structures" in Peru forearc basins: evidence from back-scattered electron microscope studies. In Suess, E., von Huene, R., et al., Proc. ODP, Sci. Results, 112: College Station, TX (Ocean Drilling Program), 33-41.

Kharaka, Y.K., and Mariner, R.H., 1989. Chemical geothermometers and their application to formation waters from sedimentary basins. In Naeser, N.D., and McCulloh, T.H. (Eds.), Thermal History of Sedimentary Basins: Berlin (Springer-Verlag), 99-117.

Kulm, L.D., et al., 1986. Oregon subduction zone: venting, fauna, and carbonates. Science, 231:561-566.

Kulm, L.D., and Suess, E., 1990. Relationship between carbonate deposits and fluid venting: Oregon accretionary prism. J. Geophys. Res., 95:8899-8915.

Kvenvolden, K.A., and McMenamin, M.A., 1980. Hydrates of natural gas: a review of their geologic occurrence. Geol. Surv. Circ. (U.S.), 825:1-9.

Langseth, M.G., Westbrook, G.K., and Hobart, M.A., 1988. Geophysical survey of a mud volcano seaward of the Barbados Ridge accretionary complex. J. Geophys. Res., 93:1049-1061.

LePichon, X., Henry, P., and the Kaiko Scientific Crew, 1991. Water budgets in accretionary wedges: a comparison. Philos. Trans. R. Soc. London A, 335:315-330.

LePichon, X., Henry, P., and Lallement, S., 1990. Water flow in the Barbados accretionary complex. J. Geophys. Res., 95:8945-8967.

LePichon, X., Kobayashi, K., and Kaiko-Nankai Scientific Crew, 1992. Fluid venting activity within the eastern Nankai Trough accretionary wedge: a summary of the 1989 Kaiko-Nankai results. Earth Planet. Sci. Lett., 109:303-318.
Lindsley-Griffin, N., Kemp, A., and Swartz, J.F., 1990. Vein structures of the Peru Margin, Leg 112. In Suess, E., von Huene, R., et al., Proc. ODP, Sci. Results, 112: College Station, TX (Ocean Drilling Program), 3-16.

Maltman, A., Byrne, T., Karig, D., Lallement, S., and Leg 131 Shipboard Party, 1992. Structural geological evidence from ODP Leg 131 regarding fluid flow in the Nankai prism, Japan. Earth Planet. Sci. Lett., 109:463-468.

Martin, J.B., Kastner, M., and Elderfield, H., 1991. Lithium: sources in pore fluids of Peru slope sediments and implications for oceanic fluxes. Mar. Geol., 102:281-292.

Moore, G.F., Shipley, T.H., Stoffa, P.L., Karig, D.E., Taira, A., Kuramoto, H., Tokuyama, and Suyehiro, K., 1990. Structure of the Nankai Trough accretionary zone from multichannel seismic reflection data. J. Geophys. Res., 95:8753-8765.

Moore, J.C., Mascle, A., Taylor, E., Andreieff, P., Alvarez, F., Barnes, R., Beck, C., Behrmann, J., Blanc, G., Brown, K., Clark, M., Dolan, J., Fisher, A., Gieskes, J., Hounslow, M., McLellan, P., Moran, K., Ogawa, Y., Sakai, T., Schoonmaker, J., Vrolijk, P., Wilkens, R., and Williams, C., 1988. Tectonics and hydrogeology of the northern Barbados Ridge: results from Ocean Drilling Program Leg 110. Geol. Soc. Am. Bull., 100:1578-1593.

Moum, J., and Rosenqvist, I.Th., 1958. Hydrogen (protium)-deuterium exchange in clays. Geochim. Cosmochim. Acta, 14:250-252.

O'Neil, J.R., Clayton, R.N., and Mayeda, T.K., 1969. Oxygen isotope fractionation in divalent metal carbonates. J. Chem. Phys., 51:5547-5558.

Peacock, S.M., 1990. Fluid processes in subduction zones. Science, 248:329-337.

Perry, E.A., and Hower, J., 1972. Late-stage dehydration in deeply buried pelitic sediments. AAPG Bull., 56:2013-2021.

Poreda, R.S., Jeffrey, A.W.A., Kaplan, I.R., and Craig, H., 1988. Magmatic helium in subduction-zone natural gases. Chem. Geol., 71:199-210.

Powers, M.C., 1967. Fluid-release mechanisms in compacting marine mudrocks and their importance in oil exploration. AAPG Bull., 51:1240-1254.

Primmer, T.J., and Shaw, H., 1991. Variations in the $\delta \mathrm{D}$ and $\delta^{18} \mathrm{O}$ compositions of illite-smectite in a partly overpressured Tertiary sequence from an offshore well, Texas, Gulf Coast, USA. Mar. Pet. Geol., 8:225-231.

Ritger, S., Carson, B., and Suess, E., 1987. Methane-derived authigenic carbonates formed by subduction-induced pore water expulsion along the Oregon/Washington margin. Geol. Soc. Am. Bull., 48:147-156.

Savin, S.M., and Epstein, S., 1970. The oxygen and hydrogen isotope geochemistry of clay minerals. Geochim. Cosmochim. Acta, 34:25-42.

Savin, S.M., and Lee, M., 1988. Isotopic studies of phyllosilicates. In Bailey, S.W. (Ed.), Hydrous Phyllosilicates (Exclusive of Micas). Mineral. Soc. Am., Rev. Mineral., 19:189-223.

Shipley, T.H., Houston, M.H., Buffler, R.T., Shaub, F.J., McMillen, K.J., Ladd, J.W., and Worzel, J.L., 1979. Seismic evidence for widespread possible gas hydrate horizons on continental slopes and rises. AAPG Bull., 63:2204-2213.

Suchecki, R.K., and Land, L.S., 1983. Isotopic geochemistry of burial metamorphosed volcanogenic sediments, Great Valley sequence, northern California. Geochim. Cosmochim. Acta., 47:1487-1499.

Taira, A., Hill, I., Firth, J.V., et al., 1991. Proc. ODP, Init. Repts., 131: College Station, TX (Ocean Drilling Program).

Taira, A., Hill, I., Firth, J., Berner, U., Brückmann, W., Byrne, T., Chabernaud, T., Fisher, A., Foucher, J.-P., Gamo, T., Gieskes, J., Hyndman, R., Karig, D., Kastner, M., Kato, Y., Lallement, S., Lu, R., Maltman, A., Moore, G., Moran, K., Olaffson, G., Owens, W., Pickering, K., Siena, F., Taylor, E., Underwood, M., Wilkinson, C., Yamano, M., and Zhang, J., 1992. Sediment deformation and hydrogeology of the Nankai accretionary prism: synthesis of shipboard results of ODP Leg 131. Earth Planet. Sci. Lett., 109:431-450.

von Huene, R., 1984. Tectonic processes along the front of modern convergent margins - research of the past decade. Annu. Rev. Earth Planet. Sci., $12: 359-381$.

von Huene, R., and Scholl, D., 1991. Observations at convergent margins concerning subduction, subduction erosion, and the growth of continental crust. Rev. Geophys., 29:279-316.

Vrolijk, P., Chambers, S.R., Gieskes, J.M., and O'Neil, J.R., 1990. Stable isotope ratios of interstitial fluids from the Northern Barbados Accretionary Prism, ODP Leg 110. In Moore, J.C., Mascle, A., et al., Proc. ODP, Sci. Results, 110: College Station, TX (Ocean Drilling Program), 189-205.

Vrolijk, P., Fisher, A., and Gieskes, J., 1991. Geochemical and geothermal evidence for fluid migration in the Barbados accretionary prism (ODP Leg 110). Geophys. Res. Lett., 18:947-950.

Vrolijk, P., and Sheppard, S.M.F., 1991. Syntectonic carbonate veins from the Barbados accretionary prism (ODP Leg 110): record of paleohydrology. Sedimentology, 38:671-690. 
Vrolijk, P.J., 1987. Tectonically-driven fluid flow in the Kodiak accretionary complex, Alaska. Geology, 15:466-469.

Walker, J.R., and Thompson, G.R., 1990. Structural variations in chlorite and illite in a diagenetic sequence from the Imperial Valley, California. Clays Clay Miner., 38:315-321.

Westbrook, G.K., and Smith, M.J., 1983. Long décollements and mud volcanoes: evidence from the Barbados Ridge Complex for the role of high pore-fluid pressure in the development of an accretionary complex. Geology, 11:279-283.

Whitney, G., 1990. Role of water in the smectite-to-illite reaction. Clays Clay Miner, 38:343-350.
Yamano, M., Foucher, J.P., Kinoshita, M., Fisher, A., Hyndman, R.D., and ODP Leg 131 Shipboard Scientific Party, 1992. Heat flow and fluid flow regime in the western Nankai accretionary prism. Earth Planet. Sci. Lett., $109: 451-462$.

Date of initial receipt: 9 June 1992

Date of acceptance: 28 September 1992

Ms 131SR-143
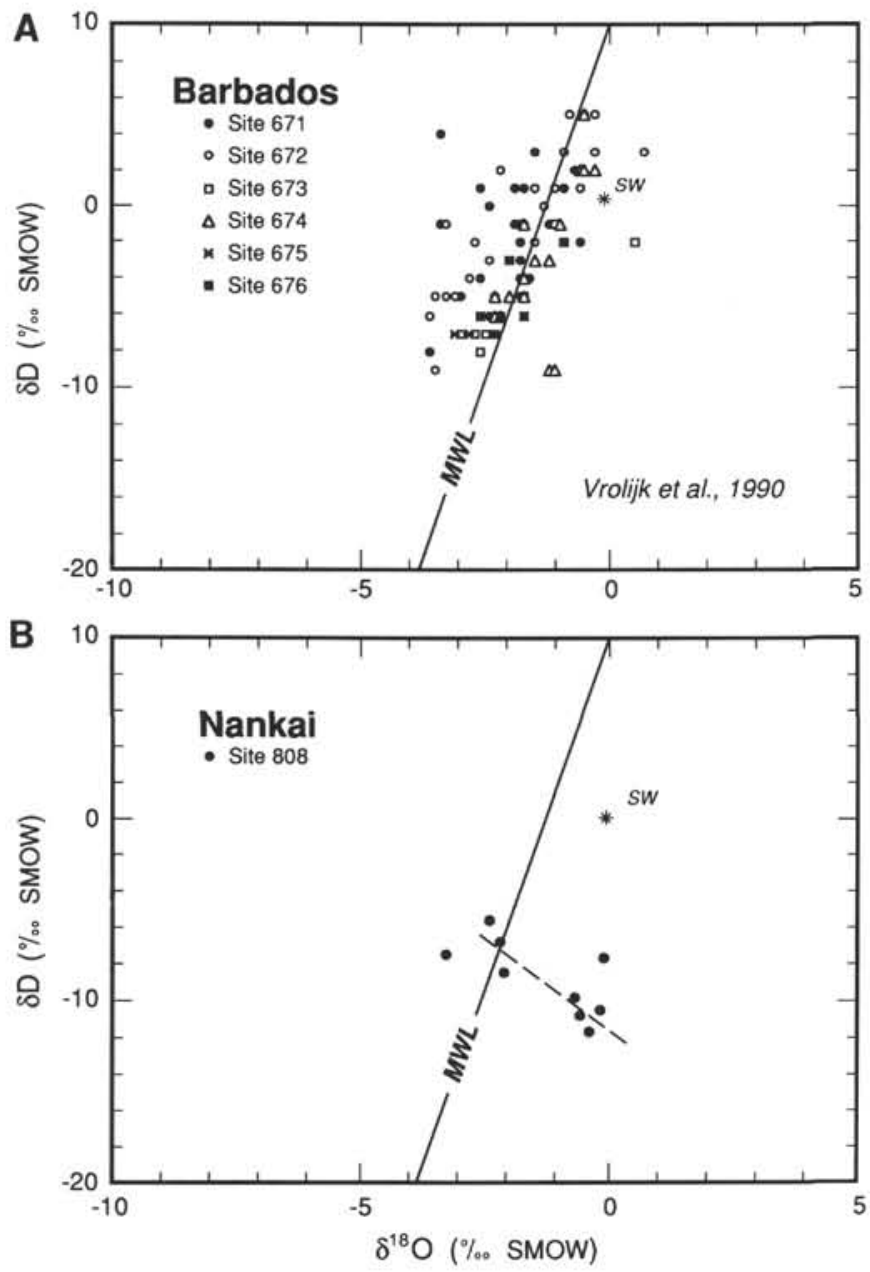

Figure 9. Plots of $\delta \mathrm{D}$ vs. $\delta^{18} \mathrm{O}$ (\%o SMOW) values of pore fluids from the two subduction zones, from (A) Barbados, and (B) western Nankai trough. The straight line is the meteoric water line (MWL) of Craig (1961), and the dashed line in (B) is a least-squares fit to the data points. Note the distinct trends of the data points at these two subduction zones. 


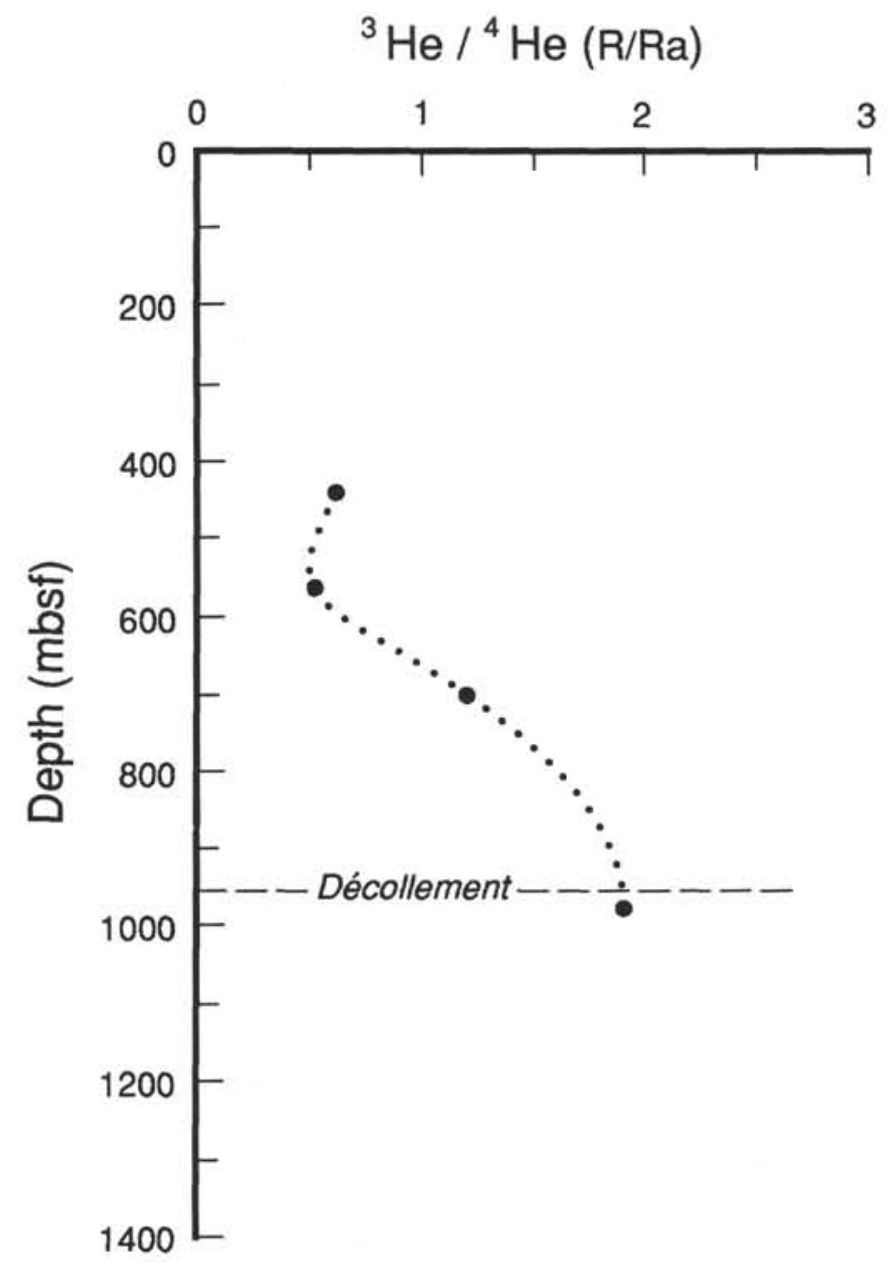

Figure 10. Depth profile of ${ }^{3} \mathrm{He} /{ }^{4} \mathrm{He}$ ratios relative to atmospheric ratio, in pore fluids from Site 808.

Table 4. Oxygen and carbon isotopic compositions of diagenetic calcites from the Nankai trough sediments, Site 808 .

\begin{tabular}{lrrrrl}
\hline $\begin{array}{c}\text { Core, section, } \\
\text { interval }(\mathrm{cm})\end{array}$ & $\begin{array}{c}\text { Depth } \\
(\mathrm{mbsf})\end{array}$ & $\begin{array}{c}\delta^{13} \mathrm{C} \\
(\% \text { PDB })\end{array}$ & $\begin{array}{c}\delta^{18} \mathrm{O} \\
(\% \text { PDB })\end{array}$ & $\begin{array}{c}\delta^{18} \mathrm{O} \\
(\% \text { SMOW })\end{array}$ & \multicolumn{1}{c}{ Comments } \\
\hline 131-808C- & & & & & \\
20X-2,31-33 & 290 & 0.87 & -0.31 & 30.54 & $\begin{array}{l}\text { Bulk sample, in thrust zone. } \\
\text { 64R-4, 2-4 }\end{array}$ \\
70R-1, 28-30 & 910 & -11.25 & -13.25 & 17.20 & $\begin{array}{l}\text { Precipitate on slickenside surface. } \\
\text { Bulk sample. }\end{array}$ \\
80R-CC, 16-19 & 1066 & -2.99 & -3.10 & 27.66 & Clear large $(\sim 1$ cm thick $)$ calcite vein. \\
80R-CC, 18-19 & 1066 & -21.93 & -14.51 & 15.91 & Small clear calcite piece. \\
\hline
\end{tabular}


A

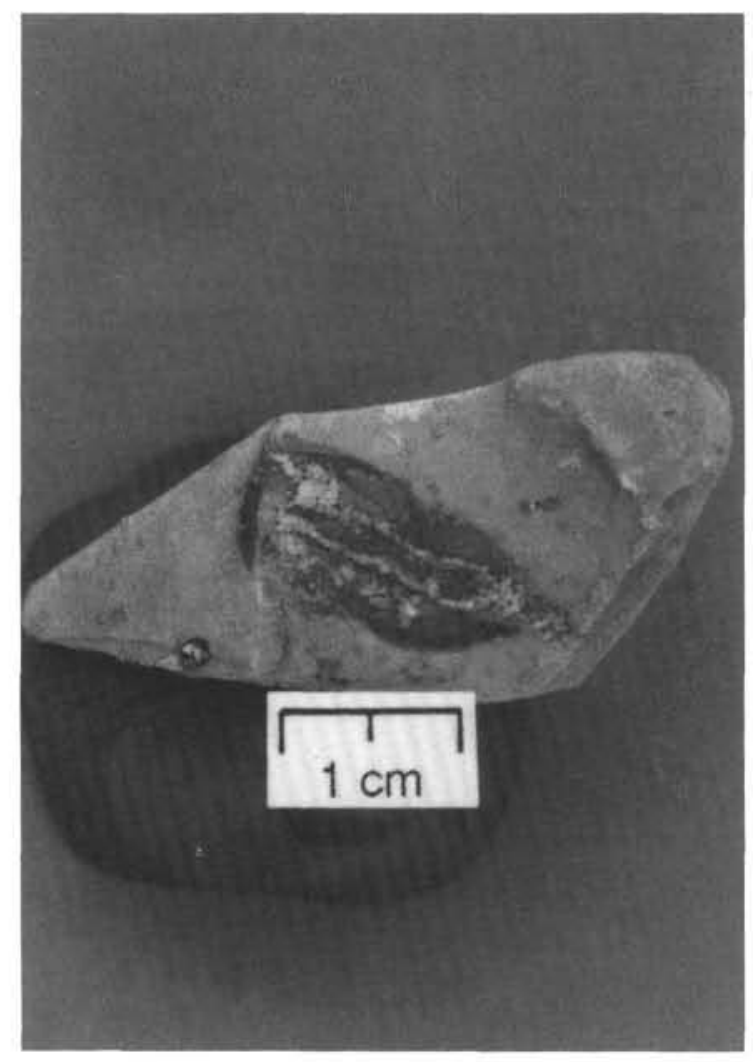

B

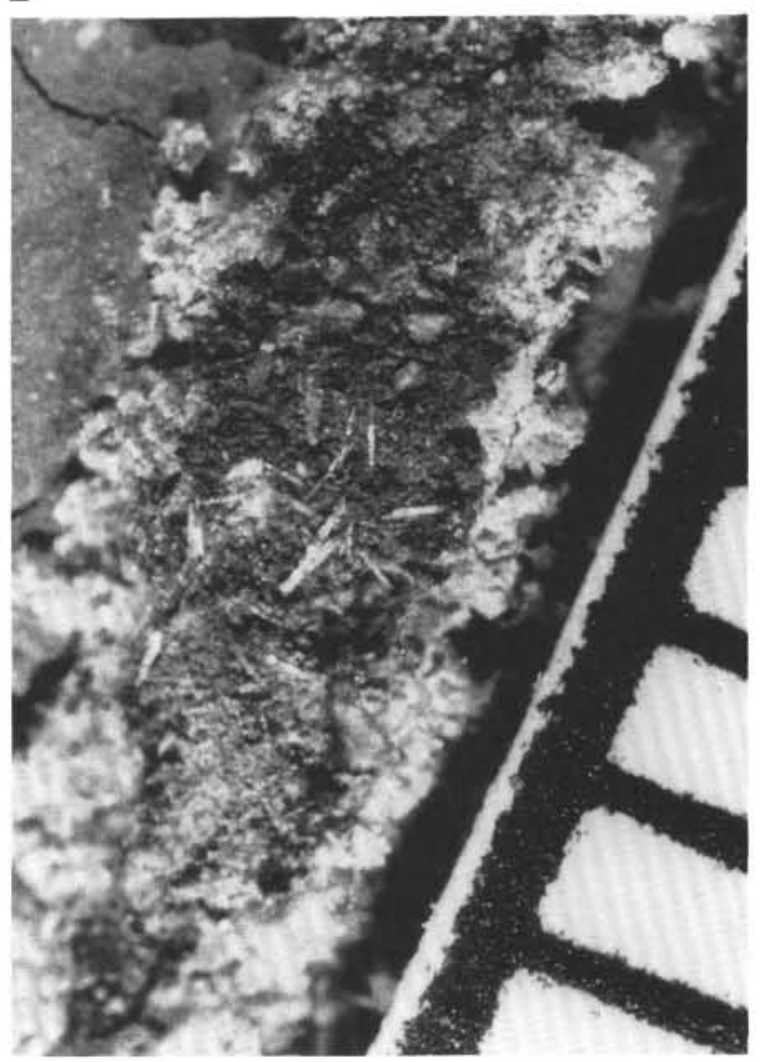

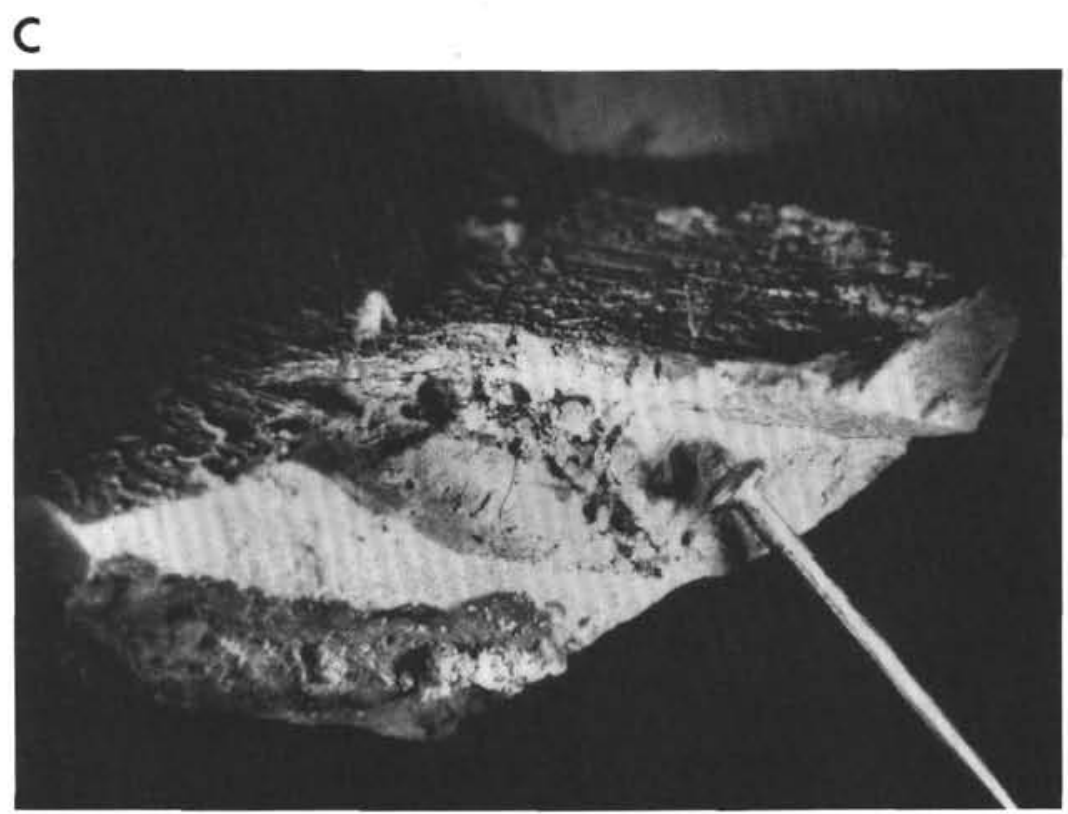

Figure 11. Photographs of typical tubular-cylindrical vein-like structures filled with dark gray to black sulfides and whitish sulfate mineral precipitates and rimmed by a halo of $\mathrm{Fe}-\mathrm{Mn}$ oxyhydroxides. (A) and (B) are different magnifications of such a structure in Sample 131-808C-64R-4, 2-4 cm, about $50 \mathrm{~m}$ above the décollement. The scale in (B) is in millimeters. C. A similar structure in Sample 131-808C-69R-3, 41-43 cm, the décollement core, is shown magnified $\times 6$. 
A

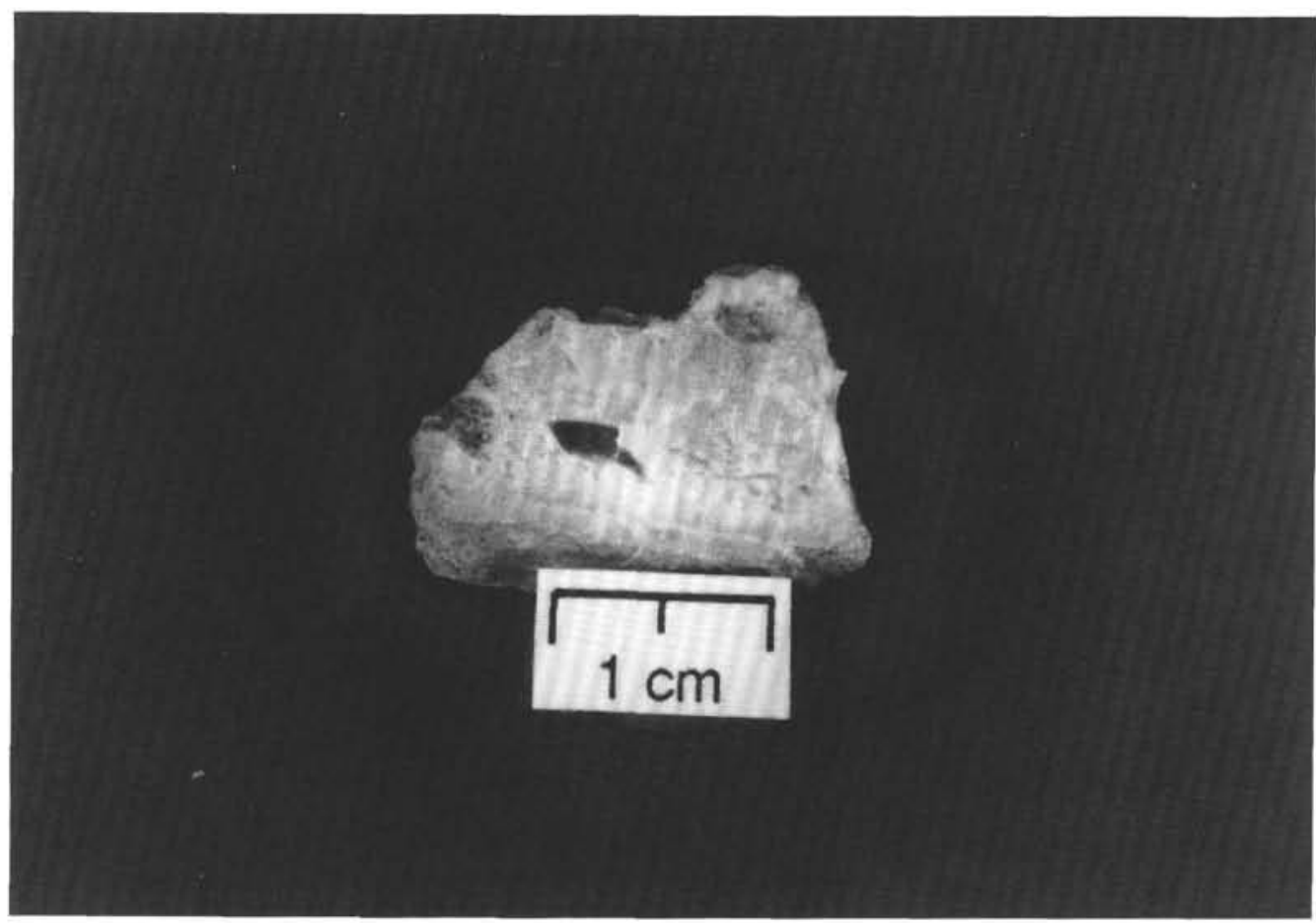

B

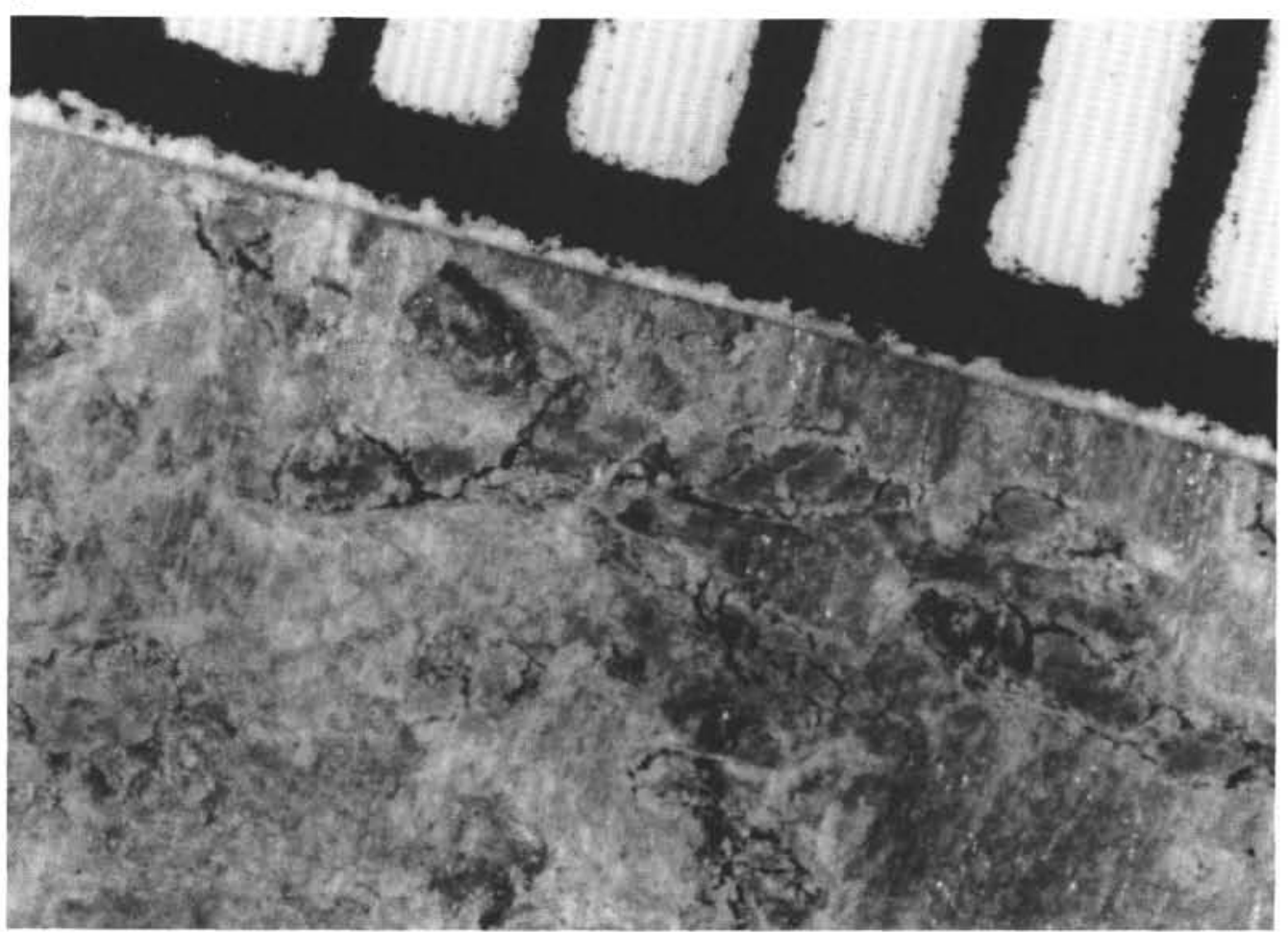

Figure 12. A piece of a $\sim 1.5 \mathrm{~cm}$ thick calcite vein in Sample 131-808C-80R-CC, $16-19 \mathrm{~cm}$, at $\sim 1066 \mathrm{mbsf}$. A. General view of the broken piece of the vein. B. Region within the vein, with abundant elongated aligned dark clay inclusions. The scale in (B) is in millimeters. 


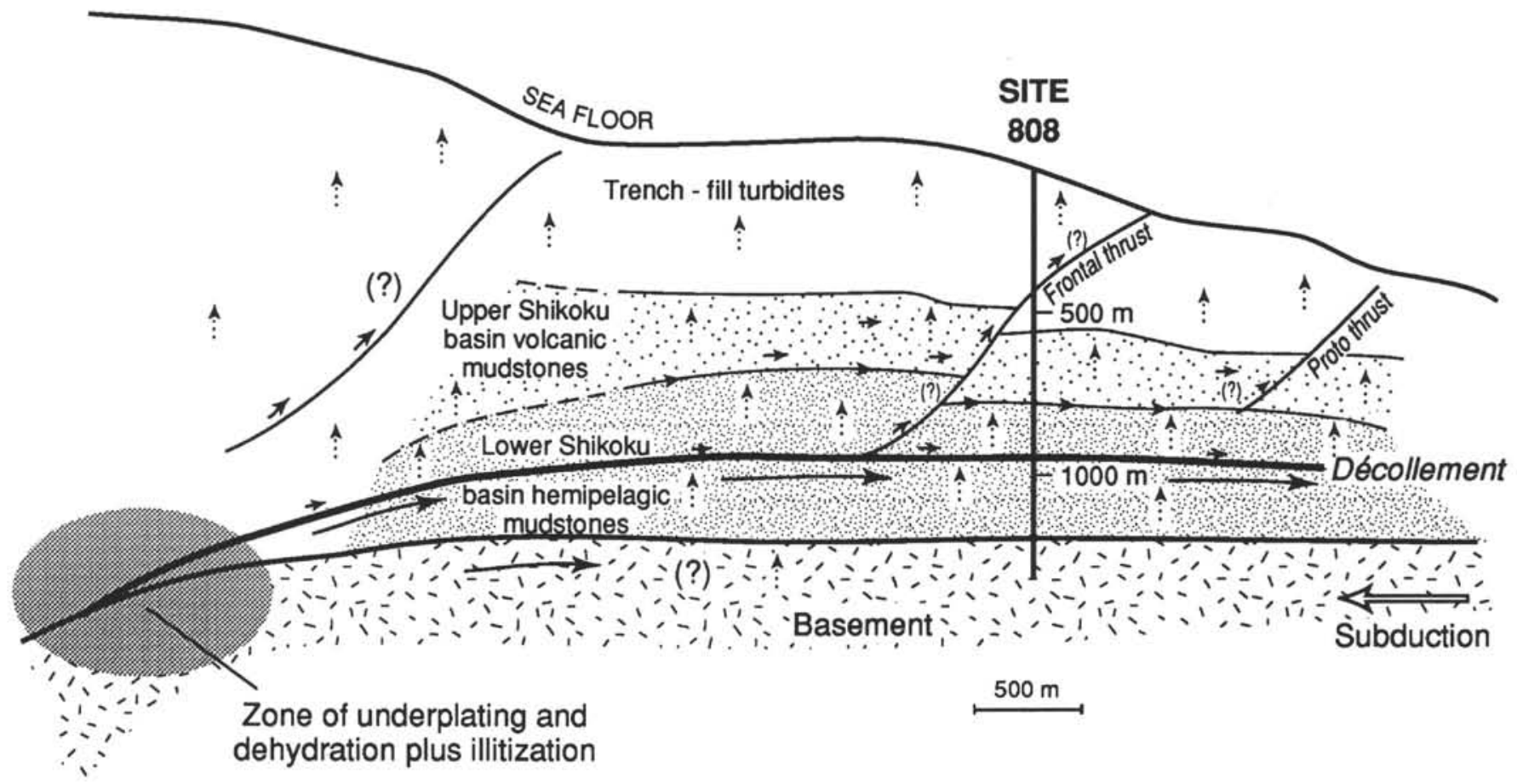

Figure 13. A schematic representation of fluid flow in the western Nankai accretionary complex. 